\title{
INCOME FROM SEPARATE PROPERTY: TOWARDS A THEORETICAL FOUNDATION
}

\author{
THOMAS R. ANDREWs*
}

\section{InTRODUCTION: The Problem STATEd}

This article addresses an important area of historical disagreement among the community property states: the characterization of the rents, issues, and profits ("income") from separate property brought into or acquired during marriage." Of the nine community property states, five characterize the income derived from separate property as separate property. ${ }^{2}$ The other four states characterize such income as community property. ${ }^{3}$ Although there have been scattered discussions of this issue throughout the community property case law and literature over the years, I have searched the literature in vain for a comprehensive treatment of the question. ${ }^{4}$ Certainly there has not been one in recent years.

The issue is important because of the prevalence of separate property in marriages. Two societal phenomena are combining to cause increasingly more separate property to be brought into marriages. First, more persons are

Copyright (C) 1993 by Law and Contemporary Problems

* Professor of Law and Associate Dean, University of Washington School of Law.

1. I will use the expression "rents, issues, and profits" interchangeably with the simpler word "income." In fact, the terminology differs from state to state. In Louisiana, the statutory term is "fruits." LA. CIV. CODE ANN. art. 551 (West 1980).

2. ARIZ. Rev. Stat. ANN. \$ 25-213 (1976); CAL. CIV. CODE §§ 5107, 5108 (West 1983); NEv. Rev. STAT. \$123.130 (1987); N.M. STAT. ANN. \& 40-3-8 (Michie 1978); WASH. REV. CODE. \& 26.16.010 (1989); see also George v. Ransom, 15 Cal. 332 (1860); Lake v. Lake, 4 P. 711 (Nev. 1884); Guye v. Guye, 114 P. 1041 (Wash. 1911).

3. IDAHO CODE \& 32-906 (1983); LA. Civ. Code ANN. art. 2339 (West 1985); TEX. FAM. CODE ANN. \& 5.01 (West 1986); WISC. STAT. ANN. \$ 766.31 (West 1990); see also Glenn v. Elam, 3 La. Ann. 611 (1848); Arnold v. Leonard, 273 S.W. 799 (Tex. 1925). Louisiana and Wisconsin allow a spouse unilaterally to avoid this characterization of income by filing an appropriate document. LA. CIV. CODE ANN. art. 2339; WIS. STAT. ANN. \$ 766.59 (West Supp. 1992). See infra parts III.A.1 to III.A.9. Unless otherwise indicated, however, I will assume as to Louisiana and Wisconsin that no such "opt-out" document has been executed.

4. The best discussions of the problem that I have found are the following: GRACE GANZ Blumberg, COMMunity Property in CaliforNia 99-101 (1987); William Q. DE FuniaK \& Michael J. VAUGHN, PRINCIPLES OF COMMUNITY PROPERTY 160-74 (2d ed. 1971); Carol S. Bruch, The Definition and Division of Marital Property in California: Towards Parity and Simplicity, 33 HASTINGS L.J. 771, 796 n.105 (1982); Edwin S. Saul, Comment, Apportionment of Income from a Spouse's Separately Owned Property, 51 CAL. L. Rev. 161, 202 (1963); Brigite M. Bodenheimer, The Community Without Community Property: The Need for Legislative Attention to Separate-Property Marriages Under Community Property Laws, 8 CAL. W. L. REV. 381, 408 (1972); F.A. LeSourd, Community Property Status of Income from Business Involving Personal Services and Separate Capital, 22 WASH. L. REV. 19, 22-24 (1947); Donald C. Knutson, California Community Property Laws: A Plea for Legislative Study and Reform, 39 S. CAL. L. REV. 240, 261-62 (1966). 
cohabiting for a significant part of their productive lives before they marry. ${ }^{5}$ They are, therefore, more likely to have property to bring to the marriage. Second, divorce ${ }^{6}$ and remarriage ${ }^{7}$ are becoming more and more common. Parties to a former marriage are more likely to bring significant separate assets to a second marriage than are those who marry for the first time. Separate property generally will generate income during the marriage. It is important to the married couple to know what the character of the income is, regardless of whether it is accumulated or spent.

Moreover, recent developments have convinced me that this question is of importance, not only to the nine community property states, but also to many of the common law property states. One of those developments, of course, is the promulgation of the Uniform Marital Property Act ("UMPA"), which has taken the position that the income from separate property should be treated as "marital property" (the Act's name for community property). ${ }^{8}$ While Wisconsin has adopted that rule as part of the UMPA, it is not at all clear that other states considering adoption of the UMPA would do so easily. Indeed, the presence of that rule in the UMPA may make the Act less palatable to historically common law states. Were the Commissioners on Uniform State Laws ("Commissioners") right in recommending that rule?

The second development also has its roots in the work of the Uniform Laws Commission, but it is a less conspicuous development than the UMPA. In 1970, the Commission promulgated the Uniform Marriage and Divorce Act ("UMDA"). Although the Act was largely concerned with nonproperty issues, it did contain a provision for property division at divorce, which essentially recommended that states adopt classic community property distinctions at the time of dissolution, as a prelude to property division. "Marital property," as defined by the UMDA, was to be divided, whereas other property was not; "marital property" was defined principally as "all property acquired by either

5. Between 1965 and $1974,11 \%$ of all people cohabited with their eventual spouse before first marrying. That number quadrupled to $44 \%$ by $1980-84$. The cohabitation rates are higher for second marriages. Between 1965 and $1974,34 \%$ of all people cohabited with their eventual spouse before a second marriage. By 1980-87, that number had risen to $60 \%$. Larry L. Bumpass \& James A. Sweet, National Estimates of Cohabitation, 26 DEMOGRAPHY 615, 619 (1989).

6. In 1960 there were 2.2 divorces per 1000 people. That rate rose to 3.5 per 1000 in 1970 and hit a high of 5.3 per 1000 in 1981 . The rate dropped somewhat in recent years (4.7 per 1000 in 1989) but that was probably due in part to the fact that there was also a decline in marriages over that period. U.S. BuREAU OF THE Census, STATISTICAL ABSTRACT OF THE UNITED STATES 87 (11th ed. 1991).

7. In $1970,31.4 \%$ of marriages involved either a remarrying bride, groom, or both. By 1980 , that number had risen to $43.8 \%$ and was $46.1 \%$ in 1987 . Id. at 62 .

8. UNIF. MARTTAL PROPERTY ACT $\S 4$ (d) (1987), 9A U.L.A. 97, 109 (1987) [hereinafter UMPA] Hereafter, I will use the terms "community property" indiscriminately to include not only that which is technically called community property in the original eight community property states, but also "marital property" under the UMPA and Wisconsin law. I will reserve the term "marital property" for the schemes of deferred community property as modeled on the Uniform Marriage and Divorce Act. See infra note 10 and accompanying text.

9. UMDA § 307, 9A U.L.A. 147, 238 (1987). 
spouse subsequent to the marriage except: bequest, devise, or descent."10

(1) property acquired by gift,

This "deferred community property" approach of the UMDA necessarily implicated the question of what to do with the income from nonmarital property. Interestingly, however, the Commissioners buried their recommended resolution of this question in the further definitional specification that nonmarital property should include the "increase in value of property acquired prior to the marriage" and in the interpretive comment to this language. The official comment states:

The phrase "increase in value" ... is not intended to cover the income from property acquired prior to the marriage. Such income is marital property. Similarly, income from other non-marital property acquired after the marriage is marital property. ${ }^{12}$

Following the promulgation of the original UMDA in 1970, the Commission substantially revised the Act in 1973, abandoning the "deferred community property" approach it had used in $1970 .^{13}$ The community property distinctions of the original UMDA seem to have found a much more sympathetic audience in the states than among the commissioners, however. Not counting the pure community property states, no fewer than twenty-seven jurisdictions have adopted some kind of marital/nonmarital distinction at divorce that is modeled on community property principles. ${ }^{14}$ Necessarily, all of these marital property

10. Id., 9A U.L.A. at 240. The full definition of "marital property" is as follows:

"marital property" means all property acquired by either spouse subsequent to the marriage except:

(1) property acquired by gift, bequest, devise, or descent;

(2) property acquired in exchange for property acquired prior to the marriage or in

exchange for property acquired by gift, bequest, devise, or descent;

(3) property acquired by a spouse after a decree of legal separation;

(4) property excluded by valid agreement of the parties; and

(5) the increase in value of property acquired prior to the marriage.

Id.

11. Six of the community property states have adopted a limited version of deferred community property to deal with some of the problems created when couples move to a community property state with marital property acquired in a common law state. This deferred community property is variously called "quasi-community property" in California, Arizona, Texas, Idaho, and Washington, CAL. PROB. CODE $\$ \S 66,101-102$ (West 1991); ARIZ. REV. STAT. ANN. \& 25-318 (1991); TEX. FAM. CODE ANN. § 3.63; IDAHO CODE $\$ \S 15-2-201$, 15-2-202 (1979); WASH. REV. CODE. $\$ 26.16 .210$, or "deferred marital property" in Wisconsin, WIS. STAT. ANN. $\$ \$ 851.055,861.02$ (West Supp. 1991). To the extent that one of these states would reclassify imported separate property as quasi-community property or deferred marital property, the problem addressed in this article-what to do with the income from separate property-goes away because the income from such property is classified in the same way as the underlying property.

12. UMDA $\S 307$ (1970), 9 U.L.A. 492 (1973) (commissioners' note).

13. The Act, as amended in 1973, directed the Court to "equitably apportion between the parties the property and assets belonging to either or both however and whenever acquired." Id., 9A U.L.A. 238 (1987).

14. Twenty-six jurisdictions have codified the distinction: ALA. CODE \& 30-2-51 (1975); ARK. CODE ANN. \$ 9-12-315 (Michie 1991); Colo. REV. STAT. \& 14-10-113 (1989); DEL. CODE ANN. tit. 13, § 1513 (1981); D.C. CODE ANN. \& 16-910 (1989); FlA. STAT. ANN. \& 61.075 (West 1991); Ill. ANN. STAT. ch. 40, I 503 (Smith-Hurd 1980); IOWA CODE ANN. $\$ 598.21$ (West 1981) (gifts and inheritances only); KAN. STAT. ANN. \$ 23-201 (1988); KY. REV. STAT. ANN. § 403.190 (Baldwin 1990); ME. REV. STAT. ANN. tit. 19, § 722-A (West 1981); MD. Code ANN., FAM. LAW \& 8-201 (1984); MiCh. STAT. ANN. $\$ 25.99$ (Callaghan 1984); MinN. STAT. ANN. $\$ 518.58$ (West 1990); Mo. ANN. STAT. $\$ 452.330$ (Vernon 1986); 
states have needed or still need to decide how to classify the income of nonmarital property if they are to continue the deferred community property approach.

In Part II, this article reviews briefly the definitional basics of the concept of income with which it will be concerned in the rest of the article. Part III examines the history of the classification of the income from separate property on the assumption that we may be able to learn from past mistakes. Those not particularly interested in the historical side of this question can safely omit this section and go on to that which follows. Following the historical examination, Part IV tries to explain what seems to be the only theoretically defensible resolution of the income problem. In doing so, the article deals with the principal objection to this preferred solution and suggests how to accommodate it.

\section{II \\ DEFINITIONAL BASICS: \\ WHAT IS INCOME FROM SEPARATE PROPERTY?}

The basic distinction with which this article is concerned is that between the underlying "principal" (including "appreciation" or "growth" in the value of property) and "income" generated by that property. ${ }^{15}$ The core concept is captured fairly well by the definition of "fruits" added to the Louisiana Civil Code in 1976:

Fruits are things that are produced by or derived from another thing without diminution of its substance. There are two kinds of fruits; natural fruits and civil fruits. Natural fruits are the products of the earth or of animals. Civil fruits are revenues derived from a thing by operation of law or by reason of a juridical act, such as rentals, interest, and certain corporate distributions. ${ }^{16}$

As this definition implies, it is pretty well established that such things as rent, ${ }^{17}$ interest, ${ }^{18}$ and animal produce ${ }^{19}$ would be considered "income" from property. ${ }^{20}$ There are also cases that treat crops, as the reference to "products of the

MONT. CODE ANN. \& 40-4-202 (1989); N.J. STAT. ANN. \& 2A:34-23 (West 1987) (gifts and inheritances only); N.Y. DOM. REL. LAW \& 236 (McKinney 1986); N.C. GEN. STAT. § 50-20 (1987); OKLA. STAT. ANN. tit. 12, $\S 121$ (West 1988) (property acquired before marriage or during marriage "by him or her in his or her own right"); 23 PA. CONS. STAT. ANN. § 3501(a) (1991); R.I. GEN. LAWS § 15-5-16.1 (1988); S.C. CoDE ANN. \$ 20-7-472 (Law. Co-op. 1976); TENN. CODE ANN. \& 36-4-121 (1984); VA. CODE ANN. § 20-107.3 (Michie 1990); W. VA. CODE § 48-2-1 (1986). 1982).

The 27th jurisdiction has adopted the distinction judicially: Bailey v. Bailey, 295 S.E.2d 304 (Ga.

15. Many community property cases and commentators use the expression "rents, issues and profits" as a term of art to refer to income. Louisiana uses the simpler term "fruits".

16. LA. CIV. CODE ANN. art. 551 (West 1980).

17. See, e.g., Gapsch v. Gapsch, 277 P.2d 278, 282 (Idaho 1954); Hodge v. Ellis, 268 S. W.2d 275, 282 (Tex. Civ. App.-Fort Worth 1954), rev'd on other grounds, 277 S.W.2d 900 (Tex. 1955).

18. See, e.g., Young v. Young, 549 So.2d 437 (La. Ct. App. 1989).

19. United States Fidelity \& Guar. Co. v. Milk Producers Ass'n, 383 S.W.2d 181 (Tex. Civ. App.-San Antonio 1964, writ denied).

20. See, e.g., William S. MCClanahan, Community Property Law in the United States 344 (1982); GeORge MCKAy, A TREATISE ON THE LAW OF COMMUNITY PROPERTY 210 (2d ed. 1925). 
earth" would suggest, as income. ${ }^{21}$ But there are difficulties with crops that will be discussed below. ${ }^{22}$ On the other hand, if separate property comes into the marriage and is then sold at a gain, the gain has almost universally been considered to accrue to the separate property owner absent some showing that it was caused through the application of community labor or funds. ${ }^{23}$ Nonetheless, the distinction between income and principal does pose some definitional and theoretical problems.

\section{A. Business Distributions}

The first of these difficulties involves business distributions, which come in a variety of forms. It is clear that cash dividends paid on shares of corporate stock are "income",24 generally, however, stock splits are not considered income because they result in no change to the underlying ownership interest of the stockholder. ${ }^{25}$ The classification of stock dividends is slightly more problematic since the issuance of a stock dividend often does not, in reality, reduce the market value of the existing stock, and sometimes increases it. ${ }^{26}$ Nonetheless, stock dividends are generally treated like splits on the theory that they do not increase the net equity in a company. ${ }^{27}$ Business earnings in close corporations and partnerships can create some difficulties because owners may have discretion whether to distribute them or retain them as an asset of the business. In general, the rule with earnings is that they are considered income for community property purposes once they are distributed or placed in an account against which an owner may draw. ${ }^{28}$ But where business earnings have been retained for sound business reasons, it has usually been held that they are not income that accrues to the community. ${ }^{29}$ Idaho, however, distinguishes between retained corporate

21. See, e.g., McGarraugh v. McGarraugh, 177 S.W.2d 296, 300 (Tex. Civ. App.-Amarillo 1944, writ dism'd); Hanks v. Leslie, 159 S.W. 1056, 1057 (Tex. Civ. App.-Ft. Worth 1913, writ ref'd).

22. See discussion infra note 41 and accompanying text.

23. MCCLANAHAN, supra note 20, at 344; DE FUNIAK \& VAUGHN, supra note 4, at 168. This is not to say that there are not difficulties in deciding whether something is a capital gain or a "profit." In Dixon v. Sanderson, 10 S.W. 535, 536 (Tex. 1888), for example, the Texas Supreme Court held that the proceeds of a lottery ticket purchased with a wife's separate property were "profits" and therefore to be classified as community property. But in general the states are clear that capital gain in separate property is to be classified as separate property.

24. Josephson v. Josephson, 772 P.2d 1236, 1242 (Idaho Ct. App. 1989); Ameson v. Ameson, 355 N.W.2d 16, 18 (Wis. Ct. App. 1984); Bakken v. Bakken, 503 S.W.2d 315, 317 (Tex. Civ. App.-Dallas 1973, no writ).

25. Succession of Hemenway, 83 So. 2d 377, 382 (La. 1955). See generally Kenneth D. McCoy, Jr., Comment, Problems in Classification of Particular Property under Community Property Regimes, 25 LA. L. REV. 108, 131-37 (1964).

26. See McCoy, supra note 25 , at 131-32.

27. Tirado v. Tirado, 357 S.W.2d 468 (Tex. Civ. App.-Texarkana 1962, writ dism'd); Johnson v. First Nat. Bank of Fort Worth, 306 S.W.2d 927, 929 (Tex. Civ. App.-Ft. Worth 1957, no writ); Daigre v. Daigre, 83 So.2d 900, 902-03 (La. 1955).

28. Marshall v. Marshall, 735 S.W.2d 587, 595 (Tex. Ct. App.-Dallas 1987, writ denied); Guilott v. Guilott, 361 So. 2d 1271, 1275-77 (La. Ct. App. 1978); Downs v. Downs, 410 So. 2d 793, 799 (La. Ct. App. 1982); Shovlain v. Shovlain, 305 P.2d 737, 738 (Idaho 1956).

29. Josephson v. Josephson, 772 P.2d 1236, 1242 (Idaho Ct. App. 1989); Simplot v. Simplot, 526 P.2d 844, 847 (Idaho 1974); Pellerin v. Pellerin, 550 So. 2d 1250, 1253-54 (La. Ct. App. 1989); Johnson v. Bank 
earnings and retained partnership earnings, and treats the latter as income to a partner for community property purposes. ${ }^{30}$ These rules, of course, create a potential unfairness for the community if it is entitled to the income of separate property, but not to appreciation (by way of reinvestment of earnings) in the property itself. This is particularly true where the separate property owner has some power over the decision whether to retain or distribute.

\section{B. Depleting Resources}

A more difficult problem arises with those assets whose productivity depends on depleting the underlying property. The problem is implicit in the Louisiana definition, which excludes from "fruits" things that diminish the substance of the underlying property. The problem is most dramatic in the case of mineral resources. Insofar as the value of the underlying property depends on the presence of oil, gas, gold, or other minerals, production and sale of the resource will diminish not only the value, but also the substance of the underlying property. $^{31}$ For that reason, the proceeds of such production could be considered a transformation of the underlying principal and should be treated as separate property. On the other hand, if the whole of the underlying property were to be sold and invested in some other asset that generated income, the community would clearly be entitled to the income. This argues for treating at least some of the mineral royalties as income. ${ }^{32}$ Louisiana's experience with this problem illustrates the tension between these two arguments: it has gone from a rule in which all proceeds from the sale of minerals were treated as a return of principal (and so separate property) ${ }^{33}$ to one in which all are treated as community property. ${ }^{34}$ Texas has apparently taken a slightly different approach. It treats royalties, bonuses, and revenues from a mineral leasehold as a return of principal, ${ }^{35}$ but treats delay rentals ${ }^{36}$ as community property. ${ }^{37}$

of Fort Worth, 306 S.W.2d 927, 929 (Tex. Ct. App.-Ft. Worth 1957, no writ) (all involving undistributed earnings in closely held corporations).

30. Swope v. Swope, 739 P.2d 273, 279-81 (Idaho 1987).

31. In principle, of course, the problem of depleting resources is simply a special application of any situation where separate property buys something for resale in pieces. But mineral resources and other similar things cause special problems to the extent it is not easy to assign to the thing sold a specific cost.

32. Cf. UNIF. PRINCIPAL AND INCOME ACT \$ 9, 7B U.L.A. 168-69 (1985) (recommending apportionment in most cases in the context of trusts holding natural resources).

33. See generally Katherine S. Spaht \& W. Lee Hargrave, Matrimonial Regimes, in 16 LouISIANA Civil LaW TREATISE 53-56 (1989).

34. Milling v. Commissioner of Revenue, 57 So. 2d 679, 682-83 (La. 1972); LA. CIv. COdE ANN. art. 2339 , as amended in 1980 by 1980 La. Acts, No. $565, \S 2$.

35. Tirado v. Tirado, 357 S.W.2d 468, 471 (Tex. Civ. App.--Texarkana, 1962, writ dism'd); Norris v. Vaughan, 260 S.W. 2d 676, 678-79 (Tex. 1953); see generally William O. Huie, The Community Property Law of Texas, 13 TEX. Rev. Civ. StAT. ANN. \& 1, 33-36 (Vernon 1960).

36. "Delay rental" is "[r]ent, usually on oil and gas leases, paid for additional time in which to utilize land. It does not depend on oil or gas produced, does not exhaust substance of land, and resembles a bonus payment, which is an advance royalty." BLACK'S LAW DICTIONARY 425 (6th ed. 1991).

37. Commissioner v. Wilson, 76 F.2d 766 (5th Cir. 1935); Lessing v. Russek, 234 S.W.2d 891, 894 (Tex. Civ. App.-Austin 1950, writ refd n.r.e.); McGarraugh v. McGarraugh, 177 S.W.2d 296, 300 (Tex. 
Similar problems are implicit in other kinds of depleting resources. While the "issue" or offspring of animals would ordinarily be considered income from separate property upon birth, ${ }^{38}$ a depletion problem arises because the original livestock may either be sold or grow old and die. If they are sold, Idaho, at least, treats this as a return of principal, and therefore separate property. ${ }^{39}$ If, on the other hand, the original livestock are not sold but simply replaced by offspring, it is possible to credit a certain amount of the offspring to the original owner to allow preservation of the initial capital. Thus the rule has developed in Louisiana that the separate property owner of livestock gets to leave the marriage with the same number of head of livestock as he owned at the beginning. ${ }^{40}$ In principle, however, this rule should apply only if the separate property owner has not sold some of the livestock and diverted the proceeds to other investments.

Similarly, the harvesting of timber has posed problems. Under modern conceptions of tree farming, trees might seem just like any other crop that can be regrown. This analysis seems to have caused Texas to treat timber taken from separate property as income, causing its classification as $100 \%$ community property. ${ }^{41}$ But trees take much longer to grow than most crops, and once the tree crop is sold, the value of the underlying property may be seriously impaired. This problem has caused Louisiana to treat the sale of timber like a sale of the underlying property. ${ }^{42}$ Thus, we have the curious phenomenon of Louisiana treating mineral royalties as income but timber sales as a return on principal, whereas Texas does precisely the reverse! It seems that the sensible thing would be to treat trees and crops similarly, and to recognize that if there is a crop near maturity on the property at the time it enters the marriage as separate property, sale of that crop should be viewed as a return of principal, and not as income. But any future crops grown during the marriage should be income.

Civ. App.-Amarillo 1944, writ dism'd).

38. Huie, supra note 35, at 36; see also Evans v. Evans, 453 P.2d 560, 568 (Idaho 1969); Estate of Eliasen, 668 P.2d 110, 116 (Idaho 1983); Amarillo Nat. Bank v. Liston, 464 S.W.2d 395, 406 (Tex. Civ. App.-Amarillo 1970, writ refd n.r.e.); Barr v. Simpson, 117 S.W. 1041, 1042 (Tex. Civ. App. 1909, writ ref'd). Thus, one does not need to sell the "issue" or "fruits" for them to be considered community property.

39. Evans, 453 P.2d at 568 . This is a sensible approach if the livestock were held for production purposes-to generate milk, wool, or offspring, for example-but not if the livestock were raised simply for sale. In that case, some allocation between separate and community estates should be made. See infra part IV.G.

40. Talbert v. Talbert, 7 So. $2 d$ 173, 174 (La. 1942); Succession of Andrus, 60 So. 623, 625 (La. 1913); see also Huie, supra note 35, at 37 (suggesting that this may be the law of Texas as well).

41. White v. Lynch, 26 Tex. 195 (1862); Hayden v. McMillan, 23 S.W. 430, 431-32 (Tex. Civ. App. 1893, writ ref'd).

42. See Succession of Rugg, 339 So. 2d 519 (La. Ct. App. 1976); LA. Civ. Code ANN. arts. 551, 562 (West 1980), and comments thereto; but see Spaht \& Hargrave, supra note 33, at 57 (suggesting that timber would properly be considered a fruit, and therefore income, in a modern tree farm operation under the new definition of fruits). 


\section{Depreciating Resources}

Closely related to the problem of capital depletion is the problem of capital depreciation. Suppose that a spouse rents a separate property building or piece of machinery. The property will eventually wear out if not kept up. Is the separate property owner therefore entitled to a depreciation allowance before the community is credited with the income? This problem seems to have been given surprisingly little attention in the states that need to distinguish between income and principal. Professor Huie tells us that this is one of the "unanswered questions" in Texas law. ${ }^{43}$ Idaho cases have held that the income from separate property to which the community is entitled is the "net income," since to hold otherwise "would cause the community to, in time, entirely consume the separate estates." ${ }^{44}$ But these cases only seem to involve a credit for the cost of taxes, upkeep, and maintenance, and not for depreciation. Louisiana alone seems to have addressed the problem directly (although not recently), and held that the separate property owner is not entitled to a credit or reimbursement for depreciation. ${ }^{45}$ In principle, however, the separate owner should be given a credit for depreciation, just as he or she should for depletion.

\section{Trust Income}

Another, and quite unrelated, kind of problem arises in the characterization of income from a trust. A settlor of a trust may give a married beneficiary an interest in the principal of the trust, in the income, or in both. If an interest is given in the income of the trust, on the one hand the income is a gift or bequest from the settlor, and the usual community property definitions would therefore classify it as separate property. ${ }^{46}$ This result is reinforced by the special legal characteristic of a trust-legal title is in the trustee, and only an equitable title is in the beneficiary. If the beneficiary does not hold legal title to the underlying principal, it is something of a conceptual hurdle to characterize the income as fruits of that person's separate property. On the other hand, if one focuses on the equitable title of the beneficiary, one can say that the beneficiary has equitable ownership of the trust corpus, and that it would then make some sense to view the income as the fruit of that equitable separate property. The problem is compounded when we ask whether the beneficiary has an equitable interest in both principal and income, or only in the income. The equitable interest of a person who has an interest only in income is obviously very different from that of one who has an equitable interest also (or only) in principal. ${ }^{47}$ The income beneficiary obviously has some kind of equitable interest in the corpus, but a

43. Huie, supra note 35 , at 32 .

44. Martsch v. Martsch, 645 P.2d 882, 886 (Idaho 1982); Malone v. Malone, 130 P.2d 674, 678 (Idaho 1942).

45. See Succession of Ratcliff, 24 So. $2 d$ 456, 458 (La. 1946).

46. Huie, supra note 35 , at $37-38$.

47. The problem is analogous to the situation in which a spouse is given a legal life estate or leasehold in land. 
beneficiary with a right to distributions of corpus can preempt the income beneficiary's interest.

There is another consideration. If an income beneficiary is free to sell the income interest and invest the proceeds, the income generated from the proceeds at least should be community property in Idaho, Texas, and Louisiana. This last consideration points in the direction of apportioning the trust interest between the separate and community estates. ${ }^{48}$ In view of these various considerations, I am inclined to think that an express gift of trust income should generally be viewed as just that, a gift to the beneficiary, to be treated as separate property absent some expression of contrary intent by the settlor. This is the statutory approach taken in Wisconsin. ${ }^{49}$ This appears to reflect best what the settlor thought he or she was doing, and to reconcile treatment of this particular species of income with the basic definition of separate property. If the income interest is alienable, however, the community should be entitled to show for what it could be sold, and what income the proceeds could have generated. If persuasive, this evidence should secure for the community a portion of the income. Notwithstanding these theoretical difficulties, however, Louisiana and Texas cases generally seem to have decided that distributed trust income is a fruit that is to be classified as community property, regardless of the precise extent of the beneficiary's interest, whereas undistributed accumulated trust income is not considered a fruit. ${ }^{50}$

\section{E. Income Versus Appreciation}

The most intractable problem in dealing with the characterization of income from separate property, however, is in trying to preserve the distinction between income from and appreciation of the underlying principal. All of the community property states that classify the income differently than the underlying principal insist on treating appreciation in the same way as the principal. ${ }^{51}$ This was the approach taken in the Spanish system, and it has remained intact. But this raises a problem because a spouse who wishes to make separately owned capital productive may be able to do so either by investing in property that produces income that can be severed from the underlying property (for example, stocks paying dividends), or by investing in property that simply produces growth or appreciation, which can be realized by the sale of some or all of the underlying

48. Huie, supra note 35 , at 37 .

49. Wis. Stat. ANN. \& 766.31(7)(a) (West Supp. 1992).

50. Commissioner v. Porter, 148 F.2d 566, 568-69 (5th Cir. 1945) (applying Texas law); Reynolds v. Reynolds, 388 So. 2d 1135, 1138-39 (La. 1979); Marriage of Burns, 573 S.W.2d 555, 557 (Tex. Civ. App.-Texarkana 1978, writ dism'd); Buckler v. Buckler, 424 S.W.2d 514, 516 (Tex. Civ. App.-Ft. Worth 1967, writ dism'd); cf. McDonald v. Paine, 810 P.2d 259, 262-63 (Idaho 1991) (income accrued on vested interest in separate property share of trust corpus is community property); see also Huie, supra note 35, at 37-38; but see Charles S. Heard et al., Characterization of Marital Property, 39 BAYLOR L. REV. 909, 940-42 (1987) (demonstrating that the proper treatment of trust income has led to considerable confusion in Texas).

51. E.g., Gapsch v. Gapsch, 277 P.2d 278, 282-83 (Idaho 1954); see generally DE FUNIAK \& VAUGHN, supra note 4, at 168; MCCLANAHAN, supra note 20, at 344 . 
asset (for example, raw land). ${ }^{52}$ The problem is compounded because there may be tax advantages flowing from investments that appreciate in value without generating current income. ${ }^{53}$

Most important of all, the choice of which investment to make is entirely in the hands of the property owner. Thus, if state law allows classification of gain as community or separate to turn exclusively on whether the "income" or "appreciation" label attaches, the nonowner spouse is entirely at the mercy of the investment strategies of the owner spouse. I will return to this point at the end of the article, because it poses the single most important objection to the Spanish approach to handling the income from separate property.

III

\section{Historical OVERVIEW}

\section{A. Community Property States}

U.S. community property regimes were derived, almost entirely, from the "community of gains" system that was prevalent in the Spanish colonies at the beginning of the 19th century. ${ }^{54}$ As noted, the Spanish community property system took the position that the income from separate property should be classified as community property. ${ }^{55}$ On the other hand, any appreciation in value of a spouse's separate property accrued to the separate property owner.

Given that U.S. community property systems originated from the Spanish system, it is not surprising that Louisiana, Texas, Idaho, and even Wisconsin have adopted the Spanish approach to characterizing income from separate property. However, it is surprising that the Spanish approach has been rejected by the other community property states, and even, to some extent, by its four adherents. ${ }^{56}$

52. The basic problem is well summarized by Professor Blumberg in her casebook. BLUMBERG, supra note 4 , at $100-01$.

53. Since capital appreciation or gain is not usually taxed until it is "realized" through the sale of the asset at a profit, income tax on such gains can be deferred by such investments. Moreover, until recently there were lower income tax rates on capital gains as opposed to ordinary income, and there is the constant possibility that such favorable rates may be reinstituted.

54. DE FUNIAK \& VAUGHN, supra note 4, at 53. That Spanish system dated at least from the late sixteenth century. Id. at 52 . There was some French influence in the development of Louisiana law, but it appears not to have been great. Id. at 65-68.

55. Id. at 160 . De Funiak and Vaughn state that this rule dated at least back to the year 1255 , and that it was "undoubtedly an original feature of the Visigothic system of marital community of property, for it appears among the Visigothic laws and customs in other parts of Europe." Id. at 161; see also Nina Nichols Pugh, The Spanish Community of Gains in 1803: Sociedad de Gananciales, 30 LA. L. REV. 1, 8-10 (1969). Where the discussion in the text calls for a shorthand description of the Spanish approach, I will refer to it simply as "the Spanish rule." Following Reppy and Samuel, I will refer to the approach that classifies income from separate property as separate simply as "the American rule." WILLIAM A. RePpy, JR. \& CYNTHia A. SAMUel, COMMUNITY PROPERTY IN THE UNITEd States 11-12 (3d ed. 1991).

56. The following historical survey focuses primarily on the period of U.S. control. Documenting whether a community property system was established in an area before American control is unnecessary for the purposes of this article. 
1. Louisiana. Chronologically, Louisiana was the first U.S. state to adopt the community property system; it did so even before statehood in 1812 . The area was a colony of France as early as 1712 , was ceded to Spain in 1763 , and was returned to France in $1800 .^{57}$ The community property system was well in place in both countries at the time, and was thus followed by each country in what was to become Louisiana. ${ }^{58}$ The first codification of Louisiana law, the Civil Code of 1808 , provided, among other things, that the "community consists of the profits of all the effects of which the husband has the administration and enjoyment ... and of the estates which they may acquire during the marriage . ..." Courts clarified early on that this included the income of either spouse's separate property, so long as it was under the management of the husband. ${ }^{60}$ From statehood until 1944, however, a wife could reserve to herself the income of her separate property by choosing to administer it. ${ }^{61}$ After 1944, the wife could reserve the income if she executed a notarized and witnessed document so stating. ${ }^{62}$ Since 1980, this rule has been gender neutral, and either spouse may unilaterally reserve the income of separate property as his or her separate property by executing an appropriate document. ${ }^{63}$ The Louisiana exception for the unilateral "opt-out" as to the income of separate property was not part of Spanish law, ${ }^{64}$ but in other respects Louisiana's statutory approach was the same as the Spanish.

57. DE FUNIAK \& VAUGHN, supra note 4, at 61-62.

58. Id. at 30-33.

59. A DIGEST OF THE CIVIL LAWS NOW IN FORCE IN THE TERRITORY OF ORLEANS art. 64 (1808) (1971 reprint). Article 69 stated that

[t] he fruits hanging by the roots on the hereditary or proper lands of either the husband or the wife, at the time of the dissolution of their marriage, are equally divided between the husband and wife or their heirs. It is the same with respect to the young of cattle yet in gestation; but the fruits of the paraphernal effects of which the wife reserved to herself the enjoyment, are excepted from the rule contained in this article.

Property "proper or hereditary" was property brought to the marriage or acquired during it by inheritance, will, or lucrative contract. Id. art. 13. Much of the 1808 Codes was incorporated without change in to the Louisiana Code of 1825 and 1870. Rodolfo Batiza, The Louisiana Civil Code of 1808: Its Actual Sources and Present Relevance, 46 TUL. L. REV. 4, 31 (1971). The provisions quoted above came into the 1870 Code virtually unchanged. REVISED CIVIL CODE OF THE STATE OF LouISIANA, arts. 2402, 2407 (1870) [hereinafter LA. CODE OF 1870]. In addition, the Code of 1870 contained an additional provision, article 2386 , which stated that "when the paraphernal property is administered by the husband ... the fruits of his property, whether natural, civil, or the result of labor, belong to the conjugal partnership ...." "Paraphernal property" was property brought into the marriage by the wife. Id. art. 2383. The wife was entitled to administer such property if she chose, but if she did not, it was under the management of her husband. Id. art. 2385.

60. Succession of Viaud v. Faurie, 11 La. Ann. 297 (1856) (fruits of husband's separate property); Fisher v. Gordy, 2 La. Ann. 762 (1847) (crops from wife's separate property, administered by husband); Webb v. Peet, 7 La. Ann. 92 (1852); Wilcox v. Henderson, 9 La. Ann. 105 (1854). See generally, HaRriet S. DAggetT, The COMMUNITy PROPERTY SYSTEM OF Louisiana 12 (1931).

61. DE FUNIAK \& VAUGHN, supra note 4 , at 161 n.97.

62. Id.

63. LA. CIV. CODE ANN. arts. 2339, 1833, 1836 (West 1985); see generally Spaht \& Hargrave, supra note 33 , at $50-51$.

64. Pugh, supra note 55, at 8-10. 
2. Texas. The adoption of the Spanish approach in Texas also occurred early, but somewhat more gradually and ambiguously than in Louisiana. It was also interrupted by an important attempt to change the rule. The original Texas Constitution of 1845 contained a basic definition of community and separate property that did not address the income problem at all.

All property, both real and personal, of the wife, owned or claimed by her before marriage, and that acquired afterwards by gift, devise, or descent, shall be her separate property; and laws shall be passed more clearly defining the rights of the wife, in relation as well to her separate property, as that held in common with her husband. ${ }^{65}$

The legislature enacted some statutes concerning marital property in 1848 , again without expressly addressing the income issue. The most relevant: (a) added a parallel definition for the separate property of the husband; (b) included in the definition of separate property "the increase of all lands or slaves ... acquired" before marriage or by gift, devise or descent; and (c) provided that "all property acquired by either husband or wife, during the marriage, except that [defined as separate property] shall be deemed the common property of the husband and wife." $" 66$

Early on, these constitutional and statutory provisions were interpreted to comport with the Spanish rule for classifying the income of separate property. The earliest reported decision directly on point seems to have been Howard $v$. York, which in 1858 held that the issue of cattle belonging to a wife would fall into the community estate. ${ }^{67}$ The court rested its decision in part on statutory and constitutional interpretation: since the income of separate property was not expressly identified as separate property in either the statute or the Constitution, the statute intended that it must therefore be the common property of the couple. ${ }^{68}$ It also relied on Spanish and Louisiana law to the same effect. ${ }^{69}$ Following Howard, courts rendered decisions similarly holding that crops grown on separate property were community property, ${ }^{70}$ and timber taken from

65. TEX. CONST. art. VII, $\$ 19$ (1845), reprinted in 2 H.P.N. GAMMEL, LAwS OF TEXAS 1293 (1898). This language has remained virtually unchanged since 1845 . 3 Vern. Ann. TEX. CoNST. art. XVI, $\$ 15$ (1993 Cum. Pocket Part); TEx. CoN. ANN. 101 (Vernon 1955). Arnold v. Leonard, 273 S.W. 799, 800801 (Tex. 1925).

66. Texas Laws 1848 , ch. $79, \S 2$, reprinted in 3 GAMMEL, supra note 65 , at 77-78.

67. 20 Tex. 670 (1858). Actually, the court in Howard relied on an unnamed decision in the prior "Galveston" term as authority. Almost certainly, the court was referring to Cartwright v. Cartwright, 18 Tex. 626 (1857), which contains an extensive discussion of the Spanish rule in an attempt to justify why the children of slaves should be treated differently. The court concluded that the children of slaves should be the property of the owner of the mother, unlike the issue of animals. The court's reasoning on this point is interesting as a matter of morality and history, and well worth noting: "Although slaves are property, yet in many respects they are persons, and are treated as such." Id. at 635 . To hold that the children of slaves belong to someone other than the owner of the mother would separate the mother from the child and this would be "repugnant to the feelings of humanity, and . . against the moral sense of the community." Id. With the abolition of slavery, this exception to the Spanish rule in Texas disappeared.

68. Cartwright, 18 Tex. at 636.

69. Id.

70. DeBlane v. Lynch, 23 Tex. 25 (1859). 
separate property was community property, ${ }^{71}$ as were the rents earned on separate personal property, ${ }^{72}$ the interest on a loan of separate property, ${ }^{73}$ rental from separate real property, ${ }^{74}$ and bricks made from clay owned as separate property. ${ }^{75}$

But in 1917, the Texas Legislature decided to reverse the income rule. In that year, the statutory definition of separate property was changed to include "the rents and revenues derived" from separate property. ${ }^{76}$ The statutory change remained on the books until it was successfully challenged on state constitutional grounds in Arnold v. Leonard in $1925 .^{77}$ The constitutional impediment, as the court saw it, was the definition of separate property.

The plain and obvious import of the language of the Constitution is to prescribe a test by which to determine when an acquest by the wife becomes a portion of the wife's separate estate ... . If the method be by gift, devise, or descent to the wife, then the Constitution makes the property belong to the wife's separate estate. If the method of acquiring during marriage be different, then the property falls without the class of separate estate of the wife, as fixed by the Constitution ....

We have no doubt that the people in adopting the Constitution in 1845, as in 1876 , understood that it was intended to put the matter of the classes of property constituting the wife's separate estate beyond legislative control. ${ }^{78}$

Accordingly, the attempted change of classification was unconstitutional. ${ }^{79}$ Significantly, the Texas Constitution, and the Arnold decision, did not expressly deal with the separate property of the husband. But the legislative attempt as to the husbands' separate property failed, owing to a technical defect, until 1929, when the legislature restored the original definitions for both spouses. ${ }^{80}$

The only other development in Texas relevant to our subject was an amendment to the Texas Constitution in 1980 providing that "if one spouse makes a gift of property to the other that gift is presumed to include all the income or property which might arise from that gift of property." ${ }^{81}$ This has the effect of presumptively changing the classification of income from separate

71. White v. Lynch, 26 Tex. 195 (1862).

72. Carr v. Tucker, 42 Tex. 330 (1875) (hiring of wife's wagon and horses).

73. Braden v. Gose, 57 Tex. 37 (1882).

74. Rhine v. Blake \& Jenkins, 59 Tex. 240 (1883); Hayden v. McMillan, 23 S.W. 430 (Tex. Civ. App. 1893, writ denied).

75. Craxton v. Ryan, 3 Tex. App. (Willson) 439 (1888).

76. Tex. Acts 1917, c. $194, \S 1$, at 436 , reprinted in 17 GAMMEL, supra note 65 , at 436 . The change was reiterated when the statute was further amended in 1921. Tex. Acts 1921, ch. 130, at 251, reprinted in 20 GAMMEL, supra note 65 , at 251 . Both changes were codified at 1 TEX. REV. CIV. STAT. ANN. $\S \S$ 4613, 4614 (1925). See generally Huie, supra note 35, at 1, 48-49; Vera L. Soronen, Amendment to Article XVI, $\$ 15$ of the Texas Constitution: Greater Uniformity Among the Community Property States, 21 S. TEX. L.J. 239, 242-43 (1980).

77. 273 S.W. 799 (Tex. 1925).

78. Id. at 801-02.

79. Id. at 803. Interestingly, the court reached the opposite conclusion as to the legislature's attempt to give the wife the exclusive right to manage the rents and revenues of her separate property-even though they are community property-and to therefore immunize such rents and revenues from community debts incurred by the husband. Id. at 804-05.

80. Tex. Laws, 1929 , c. 32, at 66 ; see generally Huie, supra note 35 , at $49-50$.

81. 3 Vern. AnN. Tex. Const., art. 16, § 15 (1993 Cum. Pocket Part). 
property for interspousal gifts. For a discussion of the reason for the 1980 change in Texas, the reader is referred to Professor McKnight's article in this volume. ${ }^{82}$

3. California. The community property system was also adopted in California in its first constitution, that of $1849 .{ }^{83}$ The key provision was identical to and borrowed from the text of 1845 Texas Constitution, which had defined the separate property of a wife. ${ }^{84}$ As with Texas, the constitutional provision was silent on the issue of classifying income from separate property. Unlike Texas, however, the California legislature addressed the issue immediately upon exercising its constitutional power to further define marital property rights. The original Act of 1850 provided that "[t]he rents and profits of the separate estate of either husband or wife shall be deemed common property." 85 Only three years later, this provision was amended to permit the instrument to specify to the contrary as to the wife. The whole provision, as amended, read:

The husband shall have the entire management and control of the common property, with the like absolute power of disposition, as of his own separate estate; and the rents and profits of the separate estate of either husband or wife shall be deemed common property; unless, in the case of the separate property of the wife, it shall be provided by the terms of the instrument whereby such property may have been bequeathed, devised or given to her, that the rents and profits thereof shall be applied to her sole and separate use. ${ }^{86}$

In 1860 , however, the statute was successfully challenged on state constitutional grounds by a wife who was seeking to avoid levy of execution on dividends from her separate property made by her husband's creditor. ${ }^{87}$ The decision in George v. Ransom bears close analysis, since it will be important in the later discussion of the rationales for the competing rules for classifying the income from separate property.

Interpreting the identical constitutional language found in the Texas Constitution-and interpreted later by the Texas Supreme Court in the Arnold case-the California Supreme Court concluded that the legislature lacked the constitutional power "to say that the fruits of the property of the wife shall be taken from her, and given to the husband or his creditors." 88 If this were allowed, it said, "the anomaly would seem to exist, of a right of property in one, divested of all beneficial use-the barren right to hold in the wife, and the

82. See generally, Joseph W. McKnight, Texas Community Property Law: Conservative Attitudes, Reluctant Change, 56 Law \& Contemp. Probs. 71 (Spring 1993).

83. CAL. CONST. art. XI, \& 14 (1849).

84. MCClanAHAN, supra note 20 , at $132 \mathrm{n} .8,168-70$. The provision is quoted in the text, supra. Professor Huie notes that the California definition must have been derived from the Texas definition. William O. Huie, The Texas Constitutional Definition of the Wife's Separate Property, 35 TEX. L. REv. 1054, 1058 (1957).

85. Cal. Laws (1850), ch. $103, \& 9$, at 254.

86. Cal. Laws (1853), ch. CXVI, $\$ 1$, at 165 , codified in CAL. GEN. LAws $1850-64, \S 3571$, at 517 (Hittell 1870).

87. George v. Ransom, 15 Cal. 322 (1860).

88. Id at 324 . 
beneficial right to enjoy in the husband." ${ }^{89}$ If the husband's creditor were permitted to reach this property, one of the provision's purposes, "to protect the wife against the improvidence of the husband," would fail. ${ }^{90}$ "The court then articulated the most important and the most interesting portion of its analysis:

It has been seen that the provision of the Constitution is, that the property acquired by the wife by devise, bequest, etc., shall be her separate property. This term "separate property" has a fixed meaning in the common law, and had in the minds of those who framed the Constitution, the large majority of whom were familiar with, and had lived under that system. By the common law, the idea attached to separate property in the wife, and which forms a portion of its definition, is, that it is an estate, held as well in its use as in its title, for the exclusive benefit and advantage of the wife. The common law recognized no such solecism as a right in the wife to the estate, and a right in some one else to use it as he pleased, and to enjoy all the advantages of its use. It is not perceived that property can be in one, in full and separate ownership, with a right in another to control it, and enjoy all of its benefits. The sole value of property is in its use; to dissociate the right of property from the use in this class of cases, would be to preserve the name - the mere shadow-and destroy the thing itself-the substance. It would be to make the wife the trustee for the husband, holding the legal title, while he held the fruits of that title. This could no more be done, in consistency with our idea of property, during the lifetime of the wife, than for all time. ${ }^{91}$

Since the court's narrow concern was to protect the wife against the husband's creditor, it might have been possible to save the classification of income from separate property as community property with a more limited holding. The court might have held, for example, that it was unconstitutional to subject either the wife's separate property or community property derived therefrom to creditors of the husband alone. ${ }^{92}$ Since the court was also concerned lest the wife lose the control and enjoyment of the fruits of her separate property, it could also have ruled that it was unconstitutional to give the husband the exclusive right to manage and dispose of those fruits as if they were his separate property.

Instead, the court concluded more broadly that any attempt to classify the income of a wife's separate property as community property was incompatible with the constitutional classification of the underlying property as separate

89. Id. Classification of the income as community property in California would have divested the wife of "all beneficial use" because California law, at the time, generally took the position that a wife had no proprietary interest in community property, but only an expectancy. See DE FUNIAK \& VAUGHN, supra note 4, at 265.

90. DE FUNIAK \& VAUGHN, supra note 4, at 265.

91. Id. at 323-24.

92. In Washington, for example, all community property is immune from either spouse's separate contractual creditors (unless the debt was incurred before marriage). WASHINGTON COMMUNITY PROPERTY DESKBOOK 6-13 to 6-14 (2d ed., 1989). Unfortunately, the opinion in George does not disclose what kind of claim underlay the judgment held by the husband's creditor there, so it is impossible to tell whether it was a debt undertaken for community purposes. This would have been critical under Washington law. But it is unlikely that California would have adopted such an approach, given its view at the time that a wife had no proprietary interest in community property. DE FUNIAK \& VAUGHN, supra note 4, at 264-66. 
property. ${ }^{93}$ This conclusion proved to be very influential in most of the other far western community property states. As we have seen, it led to an attemptalbeit unsuccessful-to change the rule in Texas. But it also led, as we shall see shortly, to a rejection of the Spanish rule in Nevada, Washington, New Mexico, and Arizona.

4. Nevada. Nevada borrowed the California/Texas constitutional provision defining a wife's separate property when it became a state in $1864 .^{94}$ It did not expressly address the classification of income from separate property, however, until 1873, when legislation was passed classifying such income as separate property. ${ }^{95}$ In addition, the classification issue under the pre-1873 statute came before the state supreme court in 1884. In a dissolution action, the wife argued that some $\$ 206,000$ in income generated by the husband's separate property should be divisible community property. ${ }^{96}$ The court noted that the Nevada constitutional provision and the relevant community property statute had been borrowed from California, but that the legislature had deliberately not included the statutory language that had been struck down in George v. Ransom. ${ }^{97}$ It assumed that the George decision was correctly decided as to the income of a wife's separate property, and concluded as a matter of policy that the income

93. Interestingly, a year after George was decided, in Lewis v. Lewis, 18 Cal. 654 (1861), the court held, without discussion, that the income from a husband's separate property was community property. Id. at 658-59. It should be noted that the statute struck down in George was still on the books, and the California Constitution contained no provision defining the separate property of the husband, as opposed to that of the wife. But the legislature ended this contradictory treatment in 1872 by declaring that the income from the separate property of either husband or wife was separate property. LeSourd, supra note 4 , at 21 .

94. MCClanAhAN, supra note 20, at 138. 1864-65 NeV. STAT. ch. 76, at 239.

95. "All property of the wife, owned by her before marriage, and that acquired by her afterwards by gift, bequest, devise, or descent, with the rents, issues, and profits thereof, is her separate property; and all property of the husband, owned by him before marriage, and that acquired by him afterwards by gift, bequest, devise, or descent, with the rents, issues, and profits thereof, is his separate property." 1873 NEV. STAT. ch. $69, \S 1$, at 193.

96. Lake v. Lake, 4 P. 711, 720 (Nev. 1884).

97. As in California, the Nevada statute of 1865 defined separate property as property owned before marriage or acquired thereafter by "gift, bequest, devise, or descent" and "common property" as "[a]ll property acquired after the marriage by either husband or wife, except such as may be acquired by gift, bequest, devise, or descent." $1864-65$ NEV. STAT. ch. 76, \$§ 1-2, at 239. Unlike California, the Nevada Legislature had not included the language struck down in George: "[T]he rents and profits of the separate property of either husband or wife shall be deemed common property." See Lake, 4 P. at 722. Curiously, however, although Nevada deleted the language thought to be critical in George, it retained related language from the California statute that presupposed that the income from separate property would ordinarily be common property. That language stated: "When it shall be provided by the terms of the instrument whereby any property may have been bequeathed, devised, or given to the wife, that the rents and profits thereof shall be applied to her sole and separate use, the entire management and control of the rents and profits of such property shall belong to the wife." 1864-65 NEV. STAT. ch. 76, $\$ 9$, at 240 . This language appears in a statute that generally gave the husband the power to manage and control his wife's separate property, without an exception where the donor had included the kind of express language allowed for income. Id. $\S 6$, at 239. Thus, this statute, like its California parent and an Idaho sibling, carved out a special category of property that a wife could exclusively manage. An interesting discussion of the intent of this language, in the context of Idaho law, may be found in William A. Reppy, Jr., Strategies for Strengthening the Case for Separate Property Classification of Assets under Idaho Law, 26 IDAHO L. REV. 425, 443-46 (1990). 
from a husband's separate property should be treated the same as that from a wife's separate property. ${ }^{98}$ After this judicial holding, the 1873 legislation classifying the income from separate property as separate property seems not to have been challenged seriously, and remains in place today. ${ }^{99}$

5. Arizona. Arizona became a territory separate from New Mexico in 1863, but did not formally adopt a community property system until $1865 .{ }^{100}$ The Territorial Act of 1865 provided that the rents and profits of the separate estate of either husband or wife should be common property, and it gave the management of this common property to the husband. ${ }^{101}$ Six years later, however, a new act was passed that provided that "[m]arried women ... shall have the sole and exclusive control of their separate property, and may convey and transfer lands or any estate or interest vested in or held by them . . . as fully and perfectly as they might be, if unmarried." 102 The 1871 Act also repealed all prior inconsistent acts.

This repealer gave the Territorial Supreme Court the opportunity to conclude, in the case of Charauleau v. Woffenden, in 1876, that the income of a wife's separate property was her separate property as well. ${ }^{103}$ At issue was a wife's right to convey unilaterally land that she had purchased, at least in part, with the income from her separate property. ${ }^{104}$ The court held that the income from her separate property was also her separate property, and that consequently she was entitled to convey the land purchased with that income. ${ }^{105}$ Although the Arizona territory had no constitutional provision on which the Court could rely, the court quoted at length from the California case, George v. Ransom, ${ }^{106}$ and was clearly convinced by its nonconstitutional reasoning. ${ }^{107}$

To say that the wife shall have the sole and exclusive control of her separate property ... and then to attach to such right the condition that when in controlling such property she receives the rents and profits thereof, such rents and profits shall become common property and under the exclusive management

98. Lake, 4 P. at 723 .

99. NEV. REV. STAT. ANN. § 123.130 (Michie 1986).

100. Charles M. SMith, Summary of Arizona Community Property Law 4 (1981).

101. Arizona Laws 1865, at 60; see also Charauleau v. Woffenden, 25 P. 652, 656 (Ariz. 1876).

102. Act of January $22,1871, \S 1$.

103. 25 P. 652, 658 (Ariz. 1876); Woffenden v. Charauleau, 25 P. 662, 664 (Ariz. 1876).

104. Charauleau, 25 P. at 658 . There were actually three cases: one an action for ejectment brought by Mr. Charauleau who alleged that he had been ousted from land he purchased from Mrs. Woffenden by Mr. Woffenden. Id. at 652 . The second was an action for forcible entry and detainer brought by $\mathrm{Mr}$. Woffenden against Charauleau, in which Mr. Woffenden sought to recover rents and profits from the land which he claimed Charauleau had wrongfully entered. Woffenden, 25 P. at 662. The third was an action brought by Mrs. Woffenden against her husband to enjoin him from interfering with her separate property. Woffenden v. Charaleau, 8 P. 302 (Ariz. 1885). Mr. Woffenden essentially lost all these actions on the basis of a holding that income from the wife's separate property was her separate property and so Mr. Charauleau's title from Mrs. Woffenden was good.

105. Woffenden, 25 P. at 664.

106. Charauleau, 25 P. at 657.

107. Id. at 657-58. 
of the husband ... is affixing a condition to the right given to her which utterly destroys the right itself. ${ }^{108}$

The matter was not entirely settled, however, since the result reached in Charauleau was questioned nine years later in a continuation of the same dispute. ${ }^{109}$ The court revisited the issue and concluded that, since the 1871 repealer did not expressly abrogate the 1865 statutory declaration that the rents of a wife's separate property were to be community, then the rents should still be community property. ${ }^{110}$ It purported to overrule its 1876 decision insofar as it was inconsistent. ${ }^{111}$ But a few months later, the court interpreted this as obiter dictum and rejected it on the ground that the principle of stare decisis required it to follow the 1876 decision. ${ }^{112}$ No doubt the court was reassured by the fact that the Arizona legislature had amended the statutes in 1885 to provide that the rents, issues, and profits of the separate property of both husbands and wives should be separate. ${ }^{113}$

This combination of judicial and legislative history, however, has put the issue to rest in Arizona. The state has treated the income of separate property as separate property ever since.

6. Idaho. Idaho's adoption of the Spanish rule was clearer than that of either Louisiana or Texas, but somewhat later. The Idaho Territory adopted a community property system in $1867 .{ }^{114}$ The original act adopting the system provided that the "rents and profits" of separate property should be community property. ${ }^{115}$ While the operative statute has changed in form since then, its

108. Woffenden, 25 P. at 664. The Court was reinforced in its conclusion by its belief that, if the wife were to sell her separate property, "the receipts of such sale, or the property in which she invests such receipts, shall become common property, and pass wholly beyond her right to use the same, or her control thereof." Id. In other words, the Court seems to have failed to draw a distinction between rents, issues, and profits, on the one hand, and the proceeds (including appreciation) from the underlying separate property, on the other.

109. Woffenden, 8 P. 302. Evidently there was some confusion over the spelling of Mr. Charaleau's name, since he appears to be the same party identified as Mr. Charauleau nine years earlier.

110. It is not entirely clear from the reports why the court felt entitled to revisit the issue in 1885 . By 1885 , the Woffendens had divorced, but Mr. Woffenden was still disputing Mr. Charaleau's claim to own the land. He sought to enjoin Charaleau from asserting any title thereto, and to have the land divided equally between himself and his former wife, as former community property. Id. at 302-03. Ultimately, the court did conclude that it was bound by its 1876 rulings, at least by the doctrine of stare decisis, if not by res judicata. Woffenden v. Charouleau, 11 P. 117, 118 (Ariz. 1886) (once again, the spelling of the name of Mrs. Woffenden's vendee has changed).

111. Woffenden, 8 P. at 304.

112. Woffenden, $11 \mathrm{P}$. at 118

113. Acts 1885, No. 5, at 5; Woffenden, 8 P. at 304 (Howard, C.J., concurring).

114. MCClANAHAN, supra note 20 , at 146 .

115. The Act provided, in relevant part, that

the rents and profits of the separate estate of either husband or wife, shall be deemed common property, unless in the case of the separate property of the wife, it shall be provided by the terms of the instrument whereby such property may have been bequeathed, devised or given to her, that the rents and profits thereof shall be applied to her sole and separate use.

Laws, Memorials and Resolutions Passed by the Fourth Legislative Assembly of the Territory of Idaho (1867), ch. IX, \& 9, at 67. 
effect has remained the same. The current language provides:

The income of all property, separate or community, is community property unless the conveyance by which it is acquired provides or both spouses, by written agreement specifically so providing, declare that . . . the income from all or specifically designated separate property be the separate property of the spouse to whom the property belongs. ${ }^{116}$

Once again, however, it should be noted that an exception to the Spanish rule has been made. Idaho classifies the income from separate property as separate property if the conveyance by which it is acquired so declares. While this is not expressed as a unilateral "opt-out" provision, as are those of Louisiana and Wisconsin, its practical consequence may be the same. ${ }^{117}$

7. Washington. Although Washington became a distinct territory in 1853 , it did not adopt a community property system until $1869 .^{118}$ The original statutes were modeled on the California statutes. ${ }^{119}$ The 1869 act addressed the income issue only obliquely, suggesting that the income of separate property was separate property by stating that the "rents and profits of [the wife's] separate property" did not need to be included in an inventory of her separate property if the underlying separate property was included. ${ }^{120}$ This ambiguous provision was replaced in 1871 by one that clearly declared the income of separate property to be community property. ${ }^{121}$ This was replaced by a statute in 1873 that failed to address the issue. ${ }^{122}$ And this, in turn, was replaced in 1879 by a provision declaring income of separate property to be separate property. ${ }^{123}$ This rule has remained in force ever since. ${ }^{124}$ Unlike Texas, California, and Nevada, however, Washington has no constitutional provision adopting the community property system. Thus, the supreme court was able, without difficulty, to give effect to the 1871 statute with respect to income from separate property that accrued during the years it was in effect. ${ }^{125}$

116. IDAHO CODE § 32-906 (1983).

117. Professor Reppy has suggested that Idaho would probably allow a separate property owner to take advantage of this provision by means of a straw party conveyance and reconveyance, at least where the original donor had not expressly declared to the contrary. Reppy, supra note 97, at 425, 447-50.

118. MCClanahan, supra note 20, at 143-44.

119. Id.

120. Laws OF Wash. Territory $1869, \S 3$, at 319.

121. 1871 WASH. LAWS $\$ 2$, at 67 , stated:

All property acquired during the marriage by the joint labors of the husband and wife, or by their individual labors, together with all rents, profits, interest or proceeds of the separate property of both accruing during the marriage, shall be common property: Provided, That the rents, profits, interest and proceeds of the wife's separate property, which shall accrue during marriage, together with her personal earnings, shall be her separate property when the same shall be necessary for the support of herself or children on account of the disability or failure of the husband to provide such support.

122. 1873 WASH. LAWS at $450-55$.

123. 1879 WASH. LAWS $\S 1$, at 77.

124. WASH. REV. CODE ANN. \$§ 26.16.010-.020 (1986).

125. Guye v. Guye, 115 P. 731 (1911). 
8. New Mexico. Although New Mexico was a distinct territory as early as 1850 , it depended largely on the laws of Spain and Mexico to define its marital property law for many years. ${ }^{126}$ A definition of separate and community property did not appear until 1901, and that did not address the income issue. ${ }^{127}$ In 1907 , however, a new statute was enacted that clearly defined the income of separate property to be separate property. ${ }^{128}$ It has been suggested that the Act of 1907 was copied almost literally from the statute then in force in California. ${ }^{129}$ Although the New Mexico statutes have changed a great deal since then, the rule as to income remains the same, ${ }^{130}$ but not without criticism. ${ }^{131}$

9. Wisconsin. While it is not surprising that Louisiana and Texas adopted the Spanish rule early on (since civil law was in place before statehood in those territories), it is surprising and theoretically more interesting that Wisconsin did so only recently. Wisconsin is, of course, the newcomer to community property in this country, enacting a community property system in 1984, to be effective in $1986 .{ }^{132}$

Interestingly, before it became a true community property state in 1986, Wisconsin had already adopted the deferred community property approach at divorce, which is widespread in what $I$ have chosen to call the marital property states. In connection with that regime, a Wisconsin appeals court in 1984 was called upon to decide how to characterize the dividends paid on stock in a foundry company, where the stock was clearly nonmarital property, having been a gift from the husband's father. ${ }^{133}$ In that case, the court concluded that the dividends should be considered marital property by following a strict statutory construction: since nothing in Wisconsin's statute on division at divorce (modeled on the UMDA) indicated that property acquired other than by gift, devise, descent, or before marriage should not be considered marital property, and nothing indicated that income generated by nonmarital property should be nonmarital, it followed that the income from excluded property should be marital

126. MCCLANAHAN, supra note 20, at 149-50.

127. 1901 N.M. LAws ch. $62, \S \S 8-33$ n, at $112-18$. The operative definition was that for separate property, called property acquired by "lucrative title"; all other property acquired during marriage was acquired by "onerous title." Id. $\S \S 2,3$. Income from separate property was not expressly included under either definition.

128. 1907 N.M. LAwS, ch. $37, \$ 88,9$, at 47.

129. MCKAY, supra note 20 , at 1065 .

130. N.M. STAT. ANN. \$ 40-3-8 (Michie Supp. 1992).

131. Laughlin v. Laughlin, 155 P.2d 1010, 1013-19 (1945); Robert Emmet Clark, New Mexico Community Property Law: The Senate Interim Committee Report, in COMPARATIVE STUDIES IN COMMUNITY PROPERTY LAW 81, 96-98 (Charmatz \& Daggett, eds., 1955).

132. 1983 Wis. Laws 186, codified at WIS. STAT. ANN. §§ 766.01-.585 (West Supp. 1992); MCClanaHAN, supra note 20, at 310 (1992 Cum. Supp.).

133. Arneson v. Arneson, 355 N.W.2d 16 (Wis. Ct. App. 1984). 
property. ${ }^{134}$ Perhaps more important, and dispositive, the court declared that "[w]e view income generated by an asset as separate and distinct from the asset itself." 135

Once it adopted a true community property statute, Wisconsin embraced the Spanish approach to characterizing the income from separate property quite explicitly, but with a Louisiana twist. Wisconsin now classifies as community property all "income ... attributable to property of a spouse during marriage" unless the spouse has executed a statement unilaterally designating the income as separate property, the separate property was a gift from the other spouse, the income was a gift in trust from a third person, or both spouses reclassify the property by agreement. ${ }^{136}$

The model, if not the original impetus, for the Wisconsin community property system was the UMPA. ${ }^{137}$ The departure from the UMPA, to allow for exceptions to the general rule that income from separate property is community, was made two years after Wisconsin adopted the UMPA model. ${ }^{138}$ Thus, in understanding Wisconsin's original decision to adopt the Spanish model, it is quite appropriate to look to the drafters of the UMPA. The Official Comment to the UMPA explains that it treats the income from separate property as community property to create "an easily comprehended system."

By treating all income from any source as marital property, the Act affords a simple and understandable arrangement. In the majority of marriages, most income will be spent sooner or later. In those so affluent that this does not happen, the rule can either be followed or changed by marital property agreement. $^{139}$

As noted, Wisconsin adopted exceptions to the UMPA (and the Spanish) approach in 1985. The principal exception, which allows a spouse to execute unilaterally a written statement making the income from separate property separate, was clearly borrowed from Louisiana. ${ }^{140}$ The 1985 changes also provide that if one spouse gives property to the other, intending that the property be the other's separate property, the income is also the other's separate

134. Id. at 20. Readers familiar with community property jurisprudence will recognize this as the "wastebasket theory" of characterization: if property does not come under one of the enumerated kinds of separate property, it falls into the "wastebasket" of community property. Marriage of Parsons, 622 P.2d 415, 416 (Wash. App. 1981).

135. Armeson, 355 N.W.2d at 20.

136. WIS. STAT. ANN. §§ 766.31(4), 766.31(7) (a), 766.31(7p), 766.31(10) (West Supp. 1991). Compare LA. CIV. CodE ANN. art. 2339 (West 1991), discussed, supra, in part III.A.1.

137. Lynn Adelman, Donald Hanaway \& Mary Lou Munts, Departures from the Uniform Marital Property Act Contained in the Wisconsin Marital Property Act, 68 MARQ. L. REV. 390, 391 (1985).

138. 1985 Wis. Laws $37, \S \S 76-83$. See WIS. STAT. ANN. $\$ \S 766.31,766.59$, Legislative Council Committee Supplemental Notes Relating to 1985 Act 37 (West Supp. 1992) [hereinafter Legislative Council Notes].

139. UMPA, cmt. to \$ 4, 9A U.L.A. 110 (1987).

140. WIS. STAT. ANN. \$ 766.59, Legislative Council Notes, supra note 138 . See also Timothy A. Bascom, Irreconcilable Differences: Income from Separate Property Under Divorce Law and Under Wisconsin's Marital Property Act, 70 MARQ. L. REV. 41 (1986). 
property unless a contrary intent is established. ${ }^{141}$ This was thought to reflect the likely intent of the donor spouse. ${ }^{142}$ A gift of income in trust from a third person is also treated as the separate property of the donee spouse, absent expression of a contrary intent in the trust instrument. ${ }^{143}$ This change was simply viewed as a "clarification." 144

\section{B. Marital Property States}

As explained earlier, in addition to the nine "pure" community property states, there are now at least twenty-seven states that employ community property principles in some way or another at the time of dissolution. ${ }^{145}$ Eighteen of these states have taken an express position on how the income from nonmarital property should be classified. Eleven states have concluded that it is nonmarital property, ${ }^{146}$ and seven have concluded that it is marital property, subject to division. ${ }^{147}$ In most of the states taking the position that income from nonmarital property is marital property, the courts have simply relied on the Commissioners' Note to the UMDA. ${ }^{148}$ And most of the states that have concluded such income is nonmarital property have done so without significant discussion of the issue. But in a few jurisdictions, the issue has been given more

141. WIS. STAT. ANN. \& 766.31(10) (West Supp. 1992). This feature of Wisconsin's law was probably borrowed from TEX. CONST. art. 16, $\$ 15$, which was amended in 1980 to include an almost identical provision. See supra Part III.A.2.

142. WIS. STAT. ANN. \& 766.31(10), Legislative Council Notes, supra note 138.

143. WIS. STAT. ANN. \& 766.31(7)(a) (West Supp. 1992).

144. Id., Legislative Council Notes, supra note 138 . As discussed earlier, however, the proper classification of trust income has been something of a problem in Louisiana and Texas. See also REPPY \& SAMUEL, supra note 55.

145. See supra note 14.

146. Seven jurisdictions have codified the characterization: ARK. CODE ANN. \& 9-12-315 (Michie Supp. 1991); FlA. STAT. ANN. $\$ 61.075$ (West Supp. 1992); ILL. ANN. STAT. ch. 40, para. 503 (SmithHurd Supp. 1992); KAN. STAT. ANN. \$ 23-201 (1988); NEB. REV. STAT. \& 42-201 (1988); N.C. GEN. STAT. \& 50-20(b)(2) (Supp. 1991); VA. CODE ANN. \& 20-107.3 (Michie 1992). See also ALA. Code \& 30-2-51 (1989) (implying that income from separate property is separate property unless used regularly for the common benefit).

The remaining four jurisdictions have adopted the characterization judicially: Marriage of Richards, 439 N.W.2d 876 (Iowa App. 1989) (treating interest on inherited CD and savings account as nonmarital property); Mount v. Mount, 476 A.2d 1175 (Md. App. 1984); Sauer v. Sauer, 459 N.Y.S.2d 131 (1983) (holding that income from separate property bonds was separate property where parties did not object); Painter v. Painter, 320 A.2d 484 (N.J. 1974) (the conclusion that "income or other usufruct derived from [separate property] shall . . be considered the separate property of the particular spouse" is "most consonant with presumed legislative intent").

147. Two jurisdictions have codified this characterization directly: R.I. GEN. LAws § 15-5-16.1 (1988) (income on property acquired before marriage); TENN. CODE ANN. \& 36-4-121 (1991) (income on separate property where other spouse has contributed to its "preservation or appreciation"). Pennsylvania's statute reaches this result indirectly by declaring that all increase in nonmarital property during marriage is marital property. 23 PA. CONS. STAT. ANN. \$\$ 3501-3503 (1991); Anthony v. Anthony, $514 \mathrm{~A} .2 \mathrm{~d} 91$ ( $\mathrm{Pa}$. Super. 1986). Assuming that rents, issues, and profits would be considered part of any "increase," it follows that these must be marital property in Pennsylvania.

The remaining five jurisdictions have adopted the characterization judicially: Halsey B.S. v. Charlotte S.S., 419 A.2d 962 (Del. Fam. Ct. 1980); Sousley v. Sousley, 614 S.W.2d 942 (Ky. 1981); Macdonald v. Macdonald, 532 A.2d 1046 (Me. 1987); Pearson v. Pearson, 363 N.W.2d 337 (Minn. App. 1985); Marriage of Schatz, 768 S.W.2d 607 (Mo. App. 1989).

148. See supra text accompanying note 12 . 
deliberate attention. This article will limit its discussion to these states, because they are fairly illustrative.

Illinois, for example, adopted the UMDA in $1977 .{ }^{149}$ Two early appeals court decisions interpreting the Illinois act classified the income from nonmarital property as marital property. The first, Marriage of Reed, ${ }^{150}$ involved interest earned during the marriage on a certificate of deposit that was brought into the marriage. The court relied on the practice notes published with the statute, which in turn relied on the commentary to the UMDA. ${ }^{151}$ The second case, Marriage of Bentivenga, ${ }^{152}$ involved interest on a nonmarital savings account. The court simply relied on the practice notes and on Reed. A third decision held that the income from a nonmarital stock trust was nonmarital property. ${ }^{153}$ There is virtually no discussion in these cases about the theoretical merits of the alternative approaches. But evidently the result recommended by the Commissioners, and adopted in Reed and Bentivenga, did not sit well with the common law heritage of Illinois. In 1983, the Illinois act was amended to classify the income from nonmarital property as nonmarital property, provided only that it did not result from the personal effort of a spouse. ${ }^{154}$

Arkansas adopted the UMDA in $1979 .{ }^{155}$ The issue of characterization of income from nonmarital property did not arise until 1986. In Speer v. Speer, ${ }^{156}$ the intermediate court of appeal held that rental income from farmland that had been acquired before marriage, or in exchange for property acquired before marriage, should be classified as marital property. The court relied on the

149. Ill. Pub. Act 80-923, ILl. ANN. STAT. ch. 40, 903 (Smith-Hurd Supp. 1992), effective Oct. 1, 1977.

150. 427 N.E.2d 282 (Ill. App. 1981).

151. See Marshall J. Auerbach \& Albert E. Jenner, Jr., Historical and Practice Notes, in ILL. ANN. STAT. ch. 40, 9 503, at 462 (Smith-Hurd 1980) (citing to commentary of UMDA to conclude that income from nonmarital property was marital property).

152. 441 N.E.2d 336 (Ill. App. 1982). Although the Bentivenga case was decided seven months after the Jones case, discussed in the text immediately following, there is no mention of the Jones case in Bentivenga.

153. Marriage of Jones, 432 N.E.2d 1113 (IIl. App. 1982) (income from nonmarital stock trust that was added to trust corpus and reinvested was nonmarital property). Although the Jones case does not provide enough information on the terms of the nonmarital trust involved in that case to be sure, it is quite possible that the case is distinguishable from those involving ordinary rents, issues, and profits cases. Where the terms of a trust give the income generated by the trust assets to a trust beneficiary, it is arguable that the trust income should be viewed as a gift-and, therefore, as separate or nonmarital property-even if it would have clearly been community property had the beneficiary owned the underlying trust assets absolutely. See, e.g., Reynolds v. Reynolds, 388 So. 2d 1135 (La. 1980) and discussion supra part II.D.

154. Ill. ANN. STAT. ch. 40, I 503, §503(a)(8); Publ. Act 83-129, effective August 19, 1983. The amended statute included in the definition of "nonmarital property" the "income" from nonmarital property "if the income is not attributable to the personal effort of a spouse." Id. See also Marriage of Deem, 463 N.E.2d 1317 (IIl. App. 1984) (following statute as amended). See also James H. Feldman \& Charles J. Fleck, Taming Transmutation: A Guide to Illinois' New Rules on Property Classification and Division upon Dissolution of Marriage, 72 ILL. B.J. 336, 338-39 (1984) (suggesting change reflected a "partnership theory of marriage"). For a discussion of the proper treatment of income from nonmarital property when it is attributable to the labor of a spouse, see discussion infra part IV.E.

155. 1979 Ark. Acts, $705 \$ 1$, codified at ARK. CODE ANN. $\$$ 9-12-315 (Michie Supp. 1991).

156. 712 S.W.2d 659 (Ark. App. 1986). 
commentary to the UMDA and on decisions from Missouri, Kansas, and Illinois. The next year, the state supreme court took the same position in Wagoner $v$. Wagoner, a case invotving the interest from a nonmarital certificate of deposit. ${ }^{157}$ The court again followed the commentary to the UMDA and held that the interest on the certificate of deposit was marital property. ${ }^{158}$ But two years later, the statute was amended to clarify that the income from nonmarital property was to be considered nonmarital property. ${ }^{159}$

Tennessee is one of only two marital property states that have codified the position that the income from nonmarital property is marital property, and it has done so in a particularly interesting manner. Its statute provides:

(b) ... (1)(A)"Marital property" means all . . . property ... acquired by either spouse or both spouses during ... marriage ...

(B) [and] includes income from, and any increase in value during the marriage, of property determined to be separate property in accordance with subdivision (b) (2) if each party substantially contributed to its preservation and appreciation....

(C) As used in this definition, "substantial contribution" may include, but not be limited to, the direct or indirect contribution of a spouse as homemaker, wage earner, parent, or family financial manager, together with such other factors as the court having jurisdiction thereof may determine....

(b)(2) "Separate property" means:

(A) All . . . property owned by a spouse before marriage; ...

(C) Income from and appreciation of property owned by a spouse before marriage except when characterized as marital property under subdivision (b)(1); and

(D) Property acquired by a spouse at any time by gift, bequest, devise or descent. ${ }^{160}$

This requirement for a "substantial contribution" by each spouse is at once narrower and broader than the proviso added in Illinois which allows for classification of income as marital property where it results from the "personal effort" of a spouse. ${ }^{161}$ It is narrower in that it seems to require both spouses to make substantial contributions. It is broader in that it defines "substantial contribution" to include a number of indirect contributions that seem to bear no clear causal relationship to the production of income from such property. Given that a spouse may "substantially contribute" to the preservation and appreciation of the other's separate property by working as a homemaker, parent or wageearner, it seems likely that virtually all income from and appreciation in separate property could be marital property under this statute. ${ }^{162}$

157. Wagoner v. Wagoner, 740 S.W.2d 915 (1987). See also Charles W. Stewart, IV, Note, Wagoner v. Wagoner: Division of Property Upon Divorce-The Classification of Returns from Separate Property, 42 ARK. L. REV. 173 (1989).

158. Wagoner, 740 S.W.2d at 915.

159. 1989 Ark. Acts 366, § 1, codified at ARK. CODE ANN. (1987) § 9-12-315(b)(7) (Michie Supp. $1991)$.

160. TENN. CODE ANN. \& 36-4-121 (1991) (emphasis added). The definition of "substantial contribution" was added in 1987. 1987 Tenn. Pub. Acts 167.

161. See discussion of Illinois law supra note 154.

162. See discussion infra at Part IV.E and note 237. 
Since the broad definition of "substantial contribution" was added only in 1987, not many published cases exist that interpret it; those that do exist, are mixed. In two cases, the court of appeals has been willing to award to the nonowning spouse a portion of the appreciation in separate property based on work as a homemaker, spouse, and parent, or as a wage-earner. ${ }^{163}$ But in two others, the court of appeals has declined to award any share of such appreciation on the basis of such indirect contributions. ${ }^{164}$ The facts and rationale of Sherrill v. Sherrill, ${ }^{165}$ which declined to award a share of appreciation to the wife, are worth recounting. Mr. Sherrill inherited stock that increased in value. Although the stock was held in a family business where Mr. Sherrill worked, the evidence showed that he drank to excess during the first seven years of the marriage and probably influenced the value of the stock negatively, whereas the wife contributed indirectly as a homemaker and parent. The husband also owned a farm on which the couple apparently lived for a year and a half, and the farm increased in value substantially. Nonetheless, the court concluded that the wife's contributions were not enough to entitle her to a share of the appreciation in either asset, because the wife did not show that her indirect contributions actually contributed to the preservation or appreciation of her husband's property. ${ }^{166}$ In essence, then, the court required the wife to show that her contributions helped cause the appreciation in her husband's property. If this interpretation prevails in other cases, it is unclear what the definition of "substantial contribution" has added to the statute.

While not exhaustive, the foregoing discussion of the treatment that our issue has received in these three marital property states is enough to show that the

163. Batson v. Batson, 769 S.W.2d 849, 859 (Tenn. App. 1988) (awarding wife a share of income from husband's separate margin accounts and rental properties, in part, because of wife's contributions as homemaker, wife, and her stepmother); Burks v. Burks, 1991 WL 12846 (Tenn. App. Feb. 8, 1991) (awarding wife $50 \%$ of $\$ 144,000$ appreciation in husband's separate stock because of wife's contributions as homemaker, parent, and her work in an unrelated real estate business).

164. Sherrill v. Sherrill, 831 S.W.2d 293 (Tenn. App. 1992) (declining to award wife a share of appreciation in husband's separate stock despite indirect contributions as homemaker); Parr v. Parr, 1988 WL 5687 (Tenn. App. Jan. 29, 1988) (declining to award wife a share of increase in husband's separate real property based on her contributions as mother, homemaker, and her work in husband's dental office).

165. Sherrill, 831 S.W.2d 293.

166. Id. To be more precise, the court of appeals declined to reverse the following finding by the trial court:

In regard to any contribution made by the Wife, the Court finds that in regard to the Wife's contributions as a homemaker and parent, in a light most favorable to the Wife, the Wife did make contributions as a parent, very similar to the contributions made by the Husband. However, the Court finds that whatever contributions the Wife made as a parent and a homemaker, such as to satisfy the "substantial contribution" aspect of the test, Wife must still show that said substantial contribution contributed to the preservation and appreciation of the Husband's inherited stocks. The Court finds the Wife failed to show that any contribution she may have made as a parent or homemaker had any direct or indirect connection whatsoever to the preservation and appreciation of the Husband's Krystal Company stockholdings. The Court finds there is no relationship, direct or indirect, between the Wife's parenting or homemaking contributions and the increase in the Krystal Company stock.

Id. at 294-95. 
issue remains important and controversial in those states. The same kind of disagreement that historically has characterized the income problem in the community property states is being played out in the marital property states as well. Most of the discussion in the marital property states has been carried out without any apparent realization that the same issue has a long and rich history in the community property states. ${ }^{167}$ There certainly has not emerged in the legislation, case law, or commentary any consensus that one approach is superior. More importantly, there has been virtually no attempt to try to understand the issue in a theoretical context that considers the purposes of the community and marital property distinctions.

\section{IV}

\section{TOWARDS A THEORETICAL UNDERSTANDING OF INCOME FROM SEPARATE}

\section{PROPERTY}

Before examining what seem to be the most important arguments for and against characterizing the income from separate property as community property, I think it will be useful to clear away some of the underbrush by dealing with arguments that have appeared in the cases and literature, but which seem to me either irrelevant or misconceived.

\section{A. Historical Argument}

The first argument is the historical argument. According to De Funiak and Vaughn, classification of the fruits and profits of separate property as community property was part of the original Spanish law of community property. ${ }^{168}$ They trace the doctrine at least to 1255 and suggest that it was drawn from the Visigoths. ${ }^{169}$ Then they criticize the California Supreme Court in George $v$. Ransom for losing touch with the principles of the Spanish system, which they felt had been incorporated into the state constitution. It would be misleading and unfair to suggest that this is the only argument relied upon by De Funiak and Vaughn. But clearly this seems to be a significant component of their advocacy of the Spanish rule. Suffice it to say that the fact that the Spanish system followed this rule is not any justification that should be persuasive to us today:

It is revolting to have no better reason for a rule of law than that so it was laid down in the time of Henry IV [or, more appropriately, Ferdinand and Isabella]. It is still more revolting if the grounds upon which it was laid down have vanished long since, and the rule simply persists from blind imitation of the past. $^{170}$

167. None of the Arkansas, Illinois, or Tennessee cases discussed above, for example, cite or refer to a decision from a community property jurisdiction.

168. DE FUNIAK \& VAUGHN, supra note 4, at $\mathbf{1 6 0 .}$

169. Id.

170. Oliver Wendell Holmes, The Path of the Law, 10 HARv. L. REv. 457, 469 (1897). 


\section{B. Constitutional Argument}

Another argument that emerged early in the debate over this topic was the contention that the proper treatment of the income from separate property was dictated by the text of the state constitutions, specifically those in Texas, California, and Nevada. These constitutions, it will be recalled, specified only that "[a]ll property, both real and personal, of the wife, owned or claimed by her before marriage, and that acquired afterwards by gift, devise, or descent, shall be her separate property." ${ }^{171}$ With this language as a constitutional backdrop, the California legislature tried to change the rule that had been in place there, and declare that the income from separate property should be community property. The California Supreme Court held, in George v. Ransom, ${ }^{172}$ that the constitution precluded that. In contrast, with the same language in its constitution, the Texas legislature tried to change the rule that had been in place there, and to make the income from separate property also separate property. The state supreme court held, in Arnold v. Leonard, ${ }^{173}$ that the Texas Constitution precluded that change. The Nevada Supreme Court, in Lake v. Lake, ${ }^{174}$ was persuaded by the California, rather than the Texas, approach, although it rested its decision more on policy than on constitutional interpretation. Since the constitutions of these states remain virtually unchanged as to the relevant language, however, one might suppose that the interpretive arguments retain whatever force they had when originally made. ${ }^{175}$

The truth of the matter, of course, is that the constitutional language did not address the income issue at all. So any constitutional interpretation of the language necessarily had to draw on the intent of the constitutional drafters, or on other sources of law, to decide whether a rule on the income issue should be read into the constitution. ${ }^{176}$ The surprising, and perhaps unfortunate, thing is that the courts in Texas and California decided that the rule did have constitutional status. Quite a bit has been written about these two cases, particularly in criticism of George v. Ransom, and any further examination of the constitutional

171. See supra notes $65,83,94$.

172. 15 Cal. 322 (1860). See supra notes 86-94 and accompanying text and discussion supra part III.A.3.

173. 273 S.W. 799 (Tex. 1925). See supra notes $76-80$ and accompanying text and discussion supra part III.A.2.

174. 4 P. 711,720 (Nev. 1884).

175. The language of the Texas and Nevada constitutions remains essentially unchanged from the original language. 3 VERN. ANN. TEX. CONST. art. 16, \& 15 (1993 Cum. Pocket Part); NEv. CONST. art. 4, \& 31. The California Constitution has been changed in form, but not in substance, to provide that "[p]roperty owned before marriage or acquired during marriage by gift, will, or inheritance is separate property." CAL. CONST. art. I, $\$ 21$.

176. The court in George v. Ransom, of course, held its rule implicit in the constitutional language on the theory that the drafters had in mind the common law meaning of "separate property." See supra note 91 and accompanying text. 
jurisprudence of the cases will not serve our purposes here. ${ }^{17}$ It is enough to observe that the consequence of these two decisions has been that the rule on income from separate property in the two most populous community property states could not be changed without a constitutional amendment or the state supreme court's reversing itself. Neither of these possibilities has ever come to pass and, as a result, the income rules of these states have become well entrenched. Moreover, as a historical matter, the constitutionalization of the income issue, particularly in California, seems to have been enormously influential. It led to an attempt-albeit unsuccessful-to change the rule in Texas, and it led to a rejection of the Spanish rule in Nevada, Washington, New Mexico, and Arizona. ${ }^{178}$

Even if the constitutions of California, Texas, or Nevada had been crystal clear as to the classification of the income from separate property, however, this would not advance the theoretical discussion one iota. This is a point that we too frequently overlook in the United States, accustomed as we are to looking at the U.S. Constitution as the ultimate criterion for "good" law. The fact of the matter is that, just as it is possible for courts to read silly rules into constitutions, it is equally possible for there to be silly rules made clear and explicit in a constitution. Constitutions are, after all, nothing more than the product of the minds-hopefully the best minds-available at a particular point in history. Thus, while they might tell us a great deal as a matter of history, politics, or even anthropology, the fact that a rule is "in" the constitution does not provide a theoretical justification for that rule. ${ }^{179}$

\section{The Common Law Argument}

Another argument that can be identified in the California Supreme Court's decision in George v. Ransom was that the attempt by the legislature to classify the income from separate property as co-owned by the spouses was inconsistent with the common law. ${ }^{180}$ The fact that such an approach was not contemplated by the common law was important, said the court, because it was the common law idea that was "in the minds of those who framed the Constitution, the large majority of whom were familiar with and had lived under that system." ${ }^{181}$

A number of commentators have noted that it was singularly inappropriate for the court in George to have drawn on common law property concepts when

177. See, e.g., Blumberg, supra note 4, at 99; DE FUNIAK \& VAUGHN, supra note 4, at 163; Bodenheimer, supra note 4, at 384-85, 408-09; Susan Westerberg Prager, The Persistence of Separate Property Concepts in California's Community Property System, 1849-1975, 24 UCLA L. REV. 1, 41-43 (1976).

178. See discussion supra parts III.A.4-5 and 7-8.

179. I recognize that some extreme legal positivists may argue that the enterprise of looking for theoretical justifications of legal rules apart from what legislatures or courts will do is misconceived. I do not have space to argue with such theorists here, but simply want to take the opportunity to acknowledge their existence and register my disagreement.

180. George, $15 \mathrm{Cal}$. at 324 . The court's language is quoted in full supra text accompanying note 91 .

181. George, 15 Cal. at 324. 
trying to discern what was appropriate for a community property system-particularly one that had been given constitutional standing. ${ }^{182}$ Professor Blumberg has remarked that the reliance on a common law notion of "separate property" is wrong, both because "separate property" is a concept unknown to the common law, and because the common law actually does provide a historical basis for separate ownership of capital and its income-the ownership of the income from, along with the possession and control of, the wife's property during marriage having historically been given to the husband. ${ }^{183}$ The irony in George is that the court seems to have been concerned primarily with protecting a wife's right to the fruits of her separate property from the creditors of her husband; to do that, the court felt it needed to resort to common law concepts. Under the law of California, community property could be reached by all of the husband's creditors. ${ }^{184}$ It is ironic because one would suppose that, at the time, a husband was more likely to have separate property than a wife. The general effect of denying community property status to the income of separate property might thus have been to deprive wives of the more favorable interpretation generally. ${ }^{185}$

But this argument against the California court's conclusion is somewhat beside the point. As a theoretical matter, the real issue is not whether the common law system or the community property system has historically made the income from one person's separate property jointly owned by both spouses during marriage. Rather, it is whether such ownership is appropriate in a community property system. That issue will be addressed shortly. But before that, it is necessary to deal with another argument made by the California court.

\section{The Value of Property Argument}

In purely theoretical terms, it seems to me that the heart of the court's reasoning in George v. Ransom is in the following sentences:

The sole value of property is in its use; to dissociate the right of property from the use in this class of cases, would be to preserve the name-the mere shadow-and destroy the thing itself-the substance .... This could no more be done, in consistency with our idea of property, during the lifetime of the wife, than for all time. ${ }^{186}$

182. See, e.g., DE FUnIAK \& VAUGHN, supra note 4, at 163; BLUMBERG, supra note 4, at 99.

183. BLUMBERG, supra note 4, at 99 . This was the so-called "jure uxoris" or estate "by the marital right." Roger A. Cunningham, William B. Stoebuck, \& Dale A. Whitman, The law of PROPERTY 77-78 (1984).

184. DE FUNIAK \& VAUGHN, supra note 4, at 163 n.5. The court could, presumably, have allowed the legislature to convert the income from the wife's separate property to the community, but held that the legislature lacked the constitutional power to expose that kind of income-as opposed to other kinds of community property-to the debts of the husband.

185. William A. Reppy, JR., Communtty Property in California: Cases, Statutes, Problems 17 n.* (2d ed. 1988). But given the fact that a California wife, at the time of George, had little more than an expectancy in community property, the advantage of a ruling that gave more community property to a wife is, at best, debatable. I am indebted to Professor Reppy for this point.

186. George, $15 \mathrm{Cal}$. at 324. 
This argument contains at least two premises that seem attractive at first, but that will not withstand examination in the context of today's community property systems. First, it asserts that the sole value of property is its use without taking into consideration the complexity of that notion of "use." Second, it assumes that in classifying the income from separate property as community property, the separate property owner's "use" of that income would be lost.

The first premise, that the sole value of property is its "use," will be true or false depending on how broadly one understands the concept of "use." But any thoughtful attempt to evaluate the court's holding is disserved by stating the proposition as simply as did the court. We recognize in our law and in our daily lives that property is really a complicated "cluster" concept. It is, as property teachers are fond of saying, something like a bundle of sticks, each stick of which is a "property" right. Depending on what you mean by the "use" of property, that right may be a larger or a smaller subset of the bundle. As to any item of property, for example, a person may have a right to use it for all purposes, or for only a limited number of purposes (circumscribed, for example, by environmental or land use regulations, or by marital property rules), and a person may have the right to use property for his or her life, or for only a limited term of years. Moreover, there are a number of incidents of ownership that we would not ordinarily think of as "uses": A person may have the right to give a property item away or not; or to sell the property or not; or to manage the property or not. ${ }^{177}$ In asserting that "the sole value of property is its use," the court grossly oversimplified the complex nature of what the "use" of property really means. It also chose to ignore incidents of property ownership that it knew were routinely denied a wife, even as to her separate property. ${ }^{188}$ As the court well knew, there is no theoretical difficulty in isolating one incident of ownership-in

187. A "bundle" theory of rights has been at the center of the community property system since its inception. For years, although the husband and wife both had vested rights in all community property, nonetheless the husband had the exclusive right to manage all the community property. So, the right to manage was divorced from the beneficial ownership. Today, as is well known, we have changed the male managerial system to a much more complicated one in which sometimes either spouse may manage an item of community property, sometimes one spouse may do so to the exclusion of another, and sometimes both spouses must join together in a managerial act. MCCLANAHAN, supra note 20, at 452-76. In most instances, either spouse may buy, sell, or obligate community property, but both spouses must join together for the sale of community realty or for gifts of community property. So the beneficial enjoyment that one spouse has in community property is not necessarily accompanied by a unilateral right to manage or give away community property. For further discussion of these management rules, see, e.g., J. Thomas Oldham, Management of the Community Estate During an Intact Marriage, 56 LAW \& CONTEMP. PROBS. 99 (Spring 1993). As these various managerial rights have changed over the years, we can see a general strengthening of the rights of a wife to be involved in management decisions. But it would be inaccurate to say that the community property system has been abolished as a result of these changes. About all one can accurately say is that the incidents of community property ownership have changed over the years.

188. It is curious that the court should have relied on such a simplistic assertion about the value of property in this context, given the extent to which California law, at the time of George, had divided the nominal ownership of property by a wife from its use and management. By statute, California (along with most of the other states) gave a husband the general right to the "management and control of the separate property of the wife during the continuance of the marriage," although sales or encumbrances of such property required the wife's joinder. CAL. GEN. LAws 1850-1864 § 3568, at 516 (Hittell 1870). 
this case the right to income-from the rest, and requiring that incident to be shared with a spouse.

The second premise in the George rationale demonstrates even more clearly why the case simply lacks theoretical force today. The court assumed that by classifying the income from the wife's separate property as community property, the wife would lose the use of the income. This would have been true at the time George was decided. California law at the time declared that the husband had the "entire management and control of the common property, with the like absolute power of disposition, as of his own separate estate."189 Court decisions had gone even further, holding that a wife really had no property interest in the community property, but only an expectancy. ${ }^{190}$ Given such a restrictive view of a wife's interest in community property, it is understandable that the California court was reluctant to allow the legislature to classify the income from a wife's separate property as community property. But that rationale cannot justify a similar reluctance today.

Today, converting the income from separate property to community property would not deprive the separate property owner of the beneficial enjoyment of that income. The separate property owner would continue to be able to enjoy its use and, in many respects, would be entitled to exclude the other spouse from managing the income, even though it has been converted to community property. ${ }^{191}$ The principal difference would be that during marriage such income would be available for community purposes and obligations, and, at the end of the marriage, it would be subject to division or disposition as community property. ${ }^{192}$

189. Id. \& 3571 , at 517.

190. Van Maren v. Johnson, 15 Cal. 308, 312 (1860) (decided the same month as George); Panaud v. Jones, 1 Cal. 488, 514-17 (1851).

191. In Texas, the separate property owner would have the exclusive right to manage the income from his or her separate property, unless and until it is commingled with other community property. TEX. FAM. CODE ANN. \& 5.22 (West 1975). In Wisconsin, the separate property owner would have the exclusive management of any community property titled in his or her name alone (as much separate property would be). WIS. STAT. ANN. $\$ 766.51(1)(\mathrm{am})$ (West Supp. 1991). In the other community property states, the spouses would have equal management rights of community property income. See generally MCCLANAHAN, supra note 20, at 216-21. But the owner of the separate property that generated the income would ordinarily have an immense practical advantage in that he or she would have the exclusive right to manage and control the underlying separate property, and the "use" of or income from that property would naturally come to him or her as separate property owner. Thus, while the separate property owner might technically not be entitled to exclude the other spouse from the enjoyment of the income during marriage, as a practical matter he or she probably could do so to a large extent.

192. As community property, the nonseparate property owning spouse would have the right, in all the community property states, to dispose of his or her half of the community income by will and, absent a will, half of the community income would pass to that spouse's heirs by intestate succession. See generally MCCLANAHAN, supra note 20, at 235-42. The income would also be subject to division as community property, rather than as separate property, at dissolution. As a consequence, the nonseparate property owner may receive a share of the income at dissolution in Arizona, California, Idaho, and Louisiana, when he or she would not have been entitled to a share had it remained separate property. Id. at 556. The other community property states allow the court to award part of one spouse's separate property to the other spouse at dissolution, so the changed classification might not have such a dramatic impact in those states. Id. at 557. 
Moreover, even though "giving" the income from separate property to the community would deprive the separate property owner of the exclusive right to use or dispose of that income during and at the end of marriage, the right to the income is only one of the important incidents of owning the separate property. The separate property "owner" would retain the right to manage the separate capital, including the right to sell it or give it away without consultation with the other spouse-carrying with it its income-producing potential. He or she would also retain the right not to use it to generate income, in short, to keep it in a sock or hold it out of use. The separate property owner would also retain the right, before marriage, to enter into a prenuptial agreement with a prospective spouse that the income from separate property would remain separate. Finally, the separate property owner would retain the right to sole ownership of the future income from separate property at the end of the marriage, either by divorce or death. Given the greater freedom with which spouses may divorce today, and the length of the average marriage, this reversion interest at the end of marriage is of significant value. ${ }^{193}$

These observations help us to evaluate the contemporary irrelevance of the George court's argument. Properly understood, it was arguing that the temporary transfer of the exclusive right to use the income from separate property would destroy a spouse's separate property right and would be inconsistent with our idea of property. Its first argument, that converting the income to the use of the community would destroy the spouse's property right, while it may have been true in 1860 , is no longer true, or is true in only a very limited sense. It is either mistaken because it erroneously considers just one of the incidents of ownership while ignoring all the others, or it is tautological, because it simply makes the point that limiting to one-half the ownership right in the income will deprive the separate property owner of the exclusive right to use the income. The court's second argument, that depriving an owner of the exclusive right to the income from property would be inconsistent with our idea of property, is equally wrong because it is contradicted by the common practice of regulating and circumscribing a few of the bundle of property rights while leaving the rest untouched. This practice, far from undermining our fundamental notion of property, gives it content.

All this shows is that to make any headway in arguing about the income issue, we must address it much more narrowly than did the California court. We must ask whether one income classification rule is more compatible with the purposes of the community property system than the other. ${ }^{194}$

193. In the context of an epoch in which marriages were more likely to last for life, the court's concern that loss of the income for the length of the marriage would destroy the essential incident of ownership may have been much more plausible than it is today.

194. The question posed, of course, assumes that a jurisdiction has already chosen the community property system over the competing common law marital property system that is prevalent in this country. 


\section{E. The Community System Argument}

De Funiak and Vaughn comment that according to the Spanish rule the classification of income from separate property as community property was based on the thought that each spouse "unselfishly and unhesitantly had at heart the success and well-being of the marital union and that, accordingly, the fruits and income of all property of each naturally were to be devoted to the benefit of the marital union." 195 As I understand it, this argument is based on the principle that sharing is fundamental to the marriage relationship. The sharing principle provides a powerful basis for preferring community property treatment of all property owned during marriage. As such, it necessarily provides a basis for saying that the income from separate property should also be community property.

The problem with the De Funiak and Vaughn argument, however, is that it proves too much. If the thesis is simply that the more property that is classified as community, the more the marital union is likely to succeed (or the more that property rules reinforce the sharing principle), then why does this "more is better" argument not lead to a "universal community of property," under which all property owned by either spouse at marriage, or at least any acquired during marriage, is classified as community property? ${ }^{196}$ To justify treating the income from separate property as community, without justifying converting all property brought into or acquired during marriage into community, a more limited argument needs to be made. Can such a limited argument find support in the conventional starting point for community property?

As De Funiak and Vaughn are fond of instructing us, the usual starting point for the community property regime is the notion that since the onerous activity of each spouse is necessary to make the marriage a "going concern," the

195. DE FUNIAK \& VAUGHN, supra note 4, at 161 . I take it that this is similar to the "sharing principle" that Professor Prager has more recently observed to be fundamental to the marriage relationship. Susan Westerberg Prager, Sharing Principles and the Future of Marital Property Law, 25 UCLA L. REV. 1 (1977).

196. Some common law (and even a few community property) states have gone part way towards a universal community of property at divorce by authorizing a court to divide all property owned by either spouse at dissolution. Clark identifies 15 common law states that do so. 2 HOMER H. CLARK, JR., THE LAW OF DOMESTIC RELATIONS IN THE UNITED STATES $178, \mathbf{n} .12$ (2d ed. 1988). This is, of course, the recommendation of the current UMDA $\$ 307$, 9A U.L.A. 238 (1987). In addition, a number of the community property states allow division or invasion of separate property at dissolution: CAL. CIV. CODE $\$ 4800.4$ (West Supp. 1992) (division of separate property limited to quasi-community property, joint tenancy and tenancy in common property); N.M. STAT. ANN. $\$ 40-4-12$ (Michie 1978) (separate property available for alimony); NEV. REV. STAT. ANN. \$ 125.150(4) (Michie Supp. 1991) (separate property available to meet spousal or child support needs); TEX. FAM. CODE ANN. \$ 3.63 (West Supp. 1992); WASH. REv. CODE ANN. \$26.09.080 (West Supp. 1992); WIS. STAT. ANN. \& 767.255 (West Supp. 1991) (separate property acquired before marriage by gift, devise, bequest, or inheritance divisible upon showing of hardship on children or other spouse; other property acquired before marriage freely divisible); see generally Lang v. Lang, 467 N.W.2d 772 (Wis. 1991); MCCLANAHAN, supra note 20, at 556-60. At death, most of the common law states provide a surviving spouse with a forced elective share against a decedent spouse's property, however acquired, WILLIAM M. MCGOVERN, JR., SHELDON F. KURTZ, \& JAN E. REIN, Wills, TRUSTS AND Estates INCluding TAXATION AND FUTURE INTERESTS 117 (1988), in some cases as much as one-half of the decedent's estate. Id. at 118. But the first to die has no corresponding right to any of the survivor's property. 
contribution of each should be recognized by treating all property acquired through that activity as common property, to be shared equally. ${ }^{197}$

[P]roperty acquired by onerous title is always community property. This is so because it is acquired by the labor and industry of members of a form of partnership . . . a marital partnership ... and whatever is earned or gained by one marital partner during the existence of the marital partnership must accrue to the benefit of both marital partners, who share equally in such earnings and gains. Such earnings and gains, even if by one spouse alone, are necessarily for the maintenance and furtherance of the marital society. They are earned or gained at the expense of the community in that the one making the earnings or gains is furthered therein by the use of the community property or by the joint efforts of the other spouse, joint efforts on the part of the other spouse which may consist, as in the case of the wife, in maintaining the home and rearing the children, for that is a sharing of the burdens of the marital partnership and a contribution to the community effort. ${ }^{198}$

Viewed from this starting point, there is at least some basis for concluding that income from separate property should fall into the community. A separate property owner or the owner's spouse may spend a substantial amount of time-indistinguishable from "onerous activity"-generating income from the separate property. With some kinds of property, at certain levels of wealth, production of income from separate property can become a full-time occupation. ${ }^{199}$

Students of community property law in this country are familiar with the difficulties that such management of separate property may occasion. Insofar as management is directly compensated, it should be generating community property. But such activity is often not directly compensated (as by a manager spouse paying himself or herself a salary). Instead, it is "invested" in the separate property that has been managed and/or improved. The difficulties become most pronounced when the separate property is placed in a business managed by one or both spouses, and the spouse is not directly compensated, or not fully compensated for his or her labor. ${ }^{200}$ In such cases, of course, the separate property may generate income or appreciate in value as a result of the labor, but whether this will yield some kind of compensation to the community for the labor invested will depend on the particular rules for characterization that are followed. The problem is not unique to the states that treat the income from separate property as separate. It also plagues the states following the Spanish rule, because, often enough, the management of separate property results in capital growth, rather than in income from the separate property. Nonetheless, the problem is more severe in the American rule states, because no share accrues

197. DE FUNIAK \& VAUGHN, supra note 4, at 24.

198. Id. at 127.

199. See, e.g., Witaschek v. Witaschek, 132 P.2d 600 (Cal. Ct. App. 1942); Nolan v. Nolan, 486 N.Y.S.2d 415 (N.Y. App. Div. 1985).

200. William J. BRockelbank, The Community Property LaW of IDaho 169-79 (1962). 
to the community immediately upon the declaration or distribution of income from the property. ${ }^{201}$

There can be no question that the various community property jurisdictions have struggled with the problem created by the uncompensated management of separate property. Following California's lead, every community property state has developed methods for compensating the community in such circumstances by giving it a share of income or appreciation in separate property. ${ }^{202}$ Nonetheless, inadequacies exist in the community property states' responses to this problem.

One such inadequacy has recently been addressed by Professor Reynolds in her thorough treatment of the problem of increases in separate property. ${ }^{203}$ She criticizes the community property states for failing adequately to take account of the extent to which appreciation in separate property is attributable to marital labor. ${ }^{204}$ For one thing, she contends that managerial decisionmaking should be considered marital effort giving rise to a marital property share. ${ }^{205}$ If it were, then decisions to invest separate property, for example, would be considered marital effort entitling the community to a share of the fruits of that decision.

I think that Professor Reynolds is quite correct in her criticism that the community property states have erred insofar as they have failed to treat time spent in managing separate property as a form of "onerous activity" that should trigger a right to a community share. ${ }^{206}$ While the predominant forms of

201. While adoption of the Spanish rule hardly solves the problem of community labor commingled with separate property, it does reduce the instances in which the problem arises, and provides some relief for the community without the need for complex allocation rules when income is, in fact, paid out to the separate property owner. Some commentators seem to have concluded that adoption of this classification rule would entirely solve the problem of commingled labor and separate property. E.g., Bodenheimer, supra note 4, at 408; LeSourd, supra note 4, at 22; Saul, supra note 4, at 202. This conclusion fails to recognize that, even with the Spanish rule, labor may be invested for the purpose of increasing the value of the separate property, and the separate property owner will typically retain the appreciation unless it produces an additional income stream. To obtain the share of that appreciation attributable to spousal labor, the claimant will need to seek an apportionment. Typically, that will not be available until the marriage is over.

202. E.g., Todd v. Commissioner of Internal Revenue, 153 F.2d 553 (9th Cir. 1945); Cockrill v. Cockrill, 601 P.2d 1334 (Ariz. 1979); Van Camp v. Van Camp, 199 P. 885 (Cal. 1921); Pereira v. Pereira, 103 P. 488 (Cal. 1909); Speer v. Quinlan, 525 P.2d 314 (Idaho 1973); Abraham v. Abraham, 87 So.2d 735 (La. 1956); Cord v. Neuhoff, 573 P.2d 1170 (Nev. 1978); Portillo v. Shappie, 636 P.2d 878 (N.M. 1981); Jensen v. Jensen, 665 S.W.2d 107 (Tex. 1984); Marriage of Elam, 650 P.2d 213 (Wash. 1982); Haldeman v. Haldeman, 426 N.W.2d 107 (Wis. Ct. App. 1988). See generally, BROCKELBANK, supra note 200, at 170-79; DE FUNIAK \& VAUGHN, supra note 4, at 168-74; REPPY \& SAMUEL, supra note 55, at 11-1 to 11-25; Bodenheimer, supra note 4, at 381-412; Donald B. King, The Challenge of Apportionment, 37 WASH. L. REV. 483 (1962); LeSourd, supra note 4, at 19, 21; J. Thomas Oldham, Separate Property Businesses that Increase in Value During Marriage, 1990 WIS. L. REV. 585 (1990); Suzanne Reynolds, Increases in Separate Property and the Evolving Marital Partnership, 24 WAKE FOREST L. REV. 239, 25883 (1989).

203. Reynolds, supra note 202 , at 258-83.

204. Id. at 268-73, 306-20.

205. Id. at 308-12.

206. Professor Reynolds is relying largely on earlier cases following the so-called "ordinary use" doctrine, under which a separate property owner was entitled to make ordinary use of his or her property without triggering a right in the other spouse to apportionment. Id. at 268-73. This doctrine 
separate property ownership may have changed since the land-based economy of the eighteenth and nineteenth centuries, ${ }^{207}$ there are obviously still many instances in which significant marital time is spent managing separate property, whether the property is land, buildings, a business, or simply investments. Such time should be treated as onerous activity, regardless of whether it is a spouse's primary vocation, and the activity should entitle the community to a share of income and appreciation attributable to such activity.

But thoroughly recognizing the contribution of onerous marital activity in this way will still not provide a foundation for classifying all income from separate property as community property. Today it is also quite common-perhaps more common-for a separate property owner to invest his or her property in a mutual fund, or with a bank or some other institutional investor or property manager, with the expectation that this hired management will generate income. While some amount of marital labor may go into the selection of the institutional managers, it does not seem plausible to argue that all the income generated by the professional manager is properly viewed as compensation for the marital decision to entrust the property to the manager. The professional manager is, after all, being compensated for the managing activities. In short, while the compensation-for-onerous-activity theory that is so basic to community property goes part of the way, it will not always support treating the income of separate property as community property in most modern cases. ${ }^{208}$

Professor Reynolds has made another argument based on unrecognized marital effort that, if correct, also applies with full force to our problem. She contends that the concept of marital effort needs to be broadened to include not only managerial decisionmaking, but also the unremunerated indirect contributions of a spouse to growth in the other spouse's separate property. ${ }^{209}$ She

seems largely to have fallen into disuse in favor of a right of apportionment. But Texas, at least, still assumes that a spouse is entitled to spend a reasonable amount of labor in managing separate property without triggering the community's right to share in the fruits of that labor. E.g., Jensen v. Jensen, 665 S.W.2d 107, 110 (Tex. 1984); Norris v. Vaughn, 260 S.W.2d 676 (Tex. 1953); Huie, supra note 35, at 33. A similar idea occasionally seems implicit in some of the decisions in other states. See, e.g., Byrd v. Babin, 159 So. 718 (La. 1935) (wife's subdivision and sale of separate land did not generate community property rights, neither compensation for her labor nor "profits"). I do not see how such an approach can be reconciled with the principle that the community is entitled to the fruits of onerous activity during marriage.

207. Professor Blumberg has rightly pointed out that the marital effort needed to manage separate property may have been at the root of the rule classifying income from separate property as community, given that ancestral land formed the core of the separate property at stake. BLUMBERG, supra note 4, at 100 . Even that contention, though, would fail to account for those who hired others to do that management activity, even in a rural economy.

208. Professor Brockelbank maintained, because of this, that the Spanish rule violated the constitutive principle that "spouses should share only what spouses earn." BROCKELBANK, supra note 200 , at 122 ("[T]here is no justification for it in symmetry, in morals, or in modern American folk ways.").

209. Reynolds, supra note 202, at 270-73. Although Professor Reynolds argues that the indirect contributions of one spouse enable the other spouse to preserve separate property, it is equally possible that such indirect contributions would allow the same spouse to preserve his or her own separate property. Necessary homemaking or child care services not provided by a spouse, for example, might have to be purchased with either spouse's separate property. See infra notes 211,212 and accompanying 
complains that while community property systems purport to value the indirect contributions of a homemaker in giving the homemaker a half-share of all "earnings" during the marriage, the community property systems inexplicably refuse to credit the same indirect contributions by one spouse to the growth-including appreciation other than realized gain -of the other spouse's separate property. ${ }^{210}$ She says, for example, that failure to credit the indirect role of such services may encourage a spouse owning separate property to "divert marital resources into separate property ... [and that] labor that might otherwise result in community property instead increases the spouse's separate estate."211

While I find this argument appealing, I do not think that it accomplishes what Professor Reynolds thinks it does. Two ways exist in which indirect contributions can enable a spouse to "divert marital resources" into separate property. One is that a spouse's indirect services may free up the other spouse to spend time managing separate property. ${ }^{212}$ But this point seems to collapse into the one made earlier: Marital efforts devoted to managing separate property should give rise to a marital share of appreciation and income. As I have said, I think this argument is correct, but it is not dependent on indirect unremunerated services for its strength.

The other way in which indirect services may permit "diversion" of marital resources is that such services may enable a family to avoid using separate property. The contribution of unremunerated services may reduce the amount that a family needs to spend to meet its needs (necessary or discretionary). If the couple chooses to spend community funds instead of separate property, or to use less separate property than otherwise might have been used, then the contributor of such services has, indeed, contributed to the preservation of separate property. But this argument really proves too much. It suggests an entitlement not just to a share of income or appreciation of separate property, or both, but to a share of the underlying separate property itself, regardless of whether it has appreciated or generated income.

I do not mean to dismiss the argument for such an entitlement. Presumably, for example, such an argument underlies the discretion given to the court in some of the community property states to divide equitably not just community property, but also separate property, at divorce. ${ }^{213}$ The full recognition of such indirect contributions arguably should lead also to recognition of an analogous discretion at the death of a spouse to divide some of the separate property. ${ }^{214}$

text.

210. Reynolds, supra note 202 , at 270-73.

211. Id. See also id. at 316. Interestingly, Tennessee seems to have adopted the approach recommended by Professor Reynolds. TENN. CODE ANN. § 36-4-121 (1984). The text of Tennessee's provision is quoted supra part III.B.

212. Reynolds, supra note 202, at 272.

213. See supra note 196.

214. In principle, either the survivor or the decedent's estate might be entitled to a share of the other's separate property, if community services indirectly contributed to income or growth in that 
Further, it can be plausibly argued that such contributions should not just be recognized by discretion in a court, but by a firm entitlement. It is also logically true that by justifying a share in the whole separate property, the argument also justifies a share in appreciation. The only shortcoming that I see in Professor Reynolds' argument is that it does not provide a basis for distinguishing between a right to a share of income and appreciation, on the one hand, and a right to the underlying principal on the other. If carried to its logical extreme, the argument would enable the community to consume the separate property of the owner rather than simply to enjoy its fruits. I find this result fundamentally inconsistent with community property's starting principles, and I am not convinced that such an extreme result is necessary to deal fairly with the problem before us. ${ }^{215}$

There is, however, another theoretical basis that provides further guidance as to how the income from and appreciation in separate property ought to be treated. The argument requires us to examine more closely what we are doing when we pledge the fruits of onerous activity to the community.

When we require the earnings and accumulations of onerous activity to be dedicated to the community, we are effectively saying to the spouses: Each of you comes to the marriage with certain human capital, and the community system requires you to dedicate the fruits of your human capital during marriage to the community's purposes. Ordinarily, of course, we use a different name for the fruits of human capital: We call them "earnings." Nonetheless, what we are fundamentally doing in the community property system is specifying that the fruits of human capital shall be community property. As we all know, this does not mean that spouses are forced to employ their human capital. Indeed, they are free not to do so. If they refrain from putting their talents to productive use, no community property is produced. We do this while recognizing that a person's human capital (such as education) remains his or her own separate property, even during marriage. This is illustrated, for example, in the law's treatment of personal injuries during marriage. Personal injuries are, of course, injuries to the human capital of a spouse. And if a spouse suffers such an injury, recoveries for this injury, over and above what is needed to compensate the community for its expenses and lost earnings, are considered separate property on the theory that they are compensation for an injury to the "individuality" or "personal security" of the spouse. ${ }^{216}$ This recognition is also illustrated in our

\footnotetext{
property.

215. I do not wish to be understood to be wedded blindly to the community property system in its existing configuration. As will be seen, I ultimately conclude that we must depart from one of the basic aspects of the system's current character to deal properly with the income problem. Nonetheless, I think that it is useful to try to remain faithful to the basic distinctions of the system unless and until they have been shown to be inadequate. I am not convinced that Professor Reynolds' argument has shown the basic distinction to be worthy of rejection in favor of a regime based on different concepts of marital sharing.

216. See, e.g., Wis. STAT. ANN. § 766.31(7)(f) (West Supp. 1991); Jurek v. Jurek, 606 P.2d 812 (Ariz. 1980); Fredrickson \& Watson Constr. Co. v. Boyd, 102 P.2d 627 (Nev. 1940); Marriage of Brown, 675 P.2d 1207 (Wash. 1984). But see CAL. CIV. CODE \& 4800(b)(4) (West Supp. 1992).
} 
general reluctance to give the community a property interest in the growth of human capital that occurs during a marriage. We do not, for example, recognize a community property interest in the educational attainments or comparable earning capacity acquired during marriage. ${ }^{217}$ This is true, it should be noted, even if the education or earning capacity required an immense expenditure of community labor or funds for its development. ${ }^{218}$ In short, it seems quite clear that the human capital that a spouse brings to the marriage, along with any improvement or growth in that human capital, remains the separate property of the spouse whose human capital it is.

What bearing does this treatment of human capital have on the income issue? It seems straightforward enough: If the community property system is to treat separate nonhuman capital in the same way in which it treats human capital, the income from such property should be considered community property. If we are to be indifferent as between different kinds of capital brought into a marriage, we should say to spouses that they must dedicate the fruits of all separate property to community purposes, regardless of whether the capital is in the form of human or nonhuman capital. ${ }^{219}$

As stated, of course, the conclusion is conditioned on the premise that we should treat both human and nonhuman capital the same. Is this premise defensible? I think there are at least two reasons for accepting it.

217. Marriage of Aufmuth, 152 Cal. Rptr. 668 (Cal. Ct. App. 1979); Wolford v. Wolford, 785 P.2d 625 (Idaho 1990); Muckleroy v. Muckleroy, 498 P.2d 1357 (N.M. 1972); Washburn v. Washburn, 677 P.2d 152 (Wash. 1984).

218. In this respect, our treatment of human capital seems to diverge from our treatment of separate nonhuman capital. As observed earlier, if marital labor is commingled with separate nonhuman capital and contributes to income or growth in that property, virtually all the community property states now recognize a community right to be compensated for its contribution to that growth either through apportionment or some right of reimbursement. The refusal to recognize a comparable right in similar growth in human capital arguably is inconsistent. The inconsistency is beginning to be realized, however, and the community property states are slowly recognizing a right to be reimbursed for such community contributions to the growth of human capital. See, e.g., CAL. CIV. CODE $\$ 4800.3$ (West Supp. 1992) (creating a right of reimbursement for community contributions to education during marriage); Marriage of Sullivan, 691 P.2d 1020 (Cal. 1984); Washburn, 677 P.2d 152 (authorizing spousal maintenance awards to take into account such contributions to education). See generally Allen M. Parkman, The Recognition of Human Capital as Property in Divorce Settlements, 40 ARK. L. REV. 439 (1987). Community property states also compensate the community for such a contribution when they recognize a property right in professional good will that is created during marriage. Mitchell v. Mitchell, 732 P.2d 208 (Ariz. 1987); Marriage of Fonstein, 552 P.2d 1169 (Cal. 1976); Marriage of Fleege, 588 P.2d 1136 (Wash. 1979). These developments, in turn, put strains on the community property system in another direction. If community contributions to the growth of separate human capital are entitled to compensation, should not separate contributions (either before marriage or during a period of separation) to separate human capital also require compensation? If they do, then some of the fruits of that human capital during marriage (that is, earnings) would need to be apportioned to the separate estate of the earning spouse. Could the community property system survive the establishment of such a principle? Could it deal with the complexity? An examination of those questions is beyond the scope of this article.

219. Since developing this theory, I have found the same notion stated briefly in Knutson, supra note 4, at 240, 261-62 ("This [Spanish] approach . . . was justified on the theory that the principal concern of each spouse is the welfare of the community and, toward that end, each contributes not only the productivity of his personal energies and abilities, but also the productivity of his personal wealth."). The theory, however, needs further elaboration and defense to be persuasive. I hope this article achieves that. 
First, a good reason not to treat the two kinds of property differently is that different treatment creates incentives for persons contemplating marriage, or spouses, to prefer one kind of investment in capital over another, when we would not want to create such incentives. If we require a spouse to dedicate the income from his or her human capital (the spouse's earnings) to the community, but allow the spouse to exclude the community from the use and ownership of the income from his or her nonhuman capital, it will be in the self-interest of that person, before or during marriage, to invest separate funds in nonhuman capital. That could have the effect, for example, of discouraging persons from spending separate funds on education or training that could increase their earning capacity during marriage, since if the separate funds were saved and invested in nonhuman capital, the fruits of the investment would remain separate.

Nonetheless, while differential treatment theoretically does provide such an incentive, we have no way of knowing who or how many persons are likely to be motivated by that incentive. We are entitled to be skeptical about claims that ordinary people typically rely on such economic calculations to lead their lives. This brings me to my second reason, which is a simple, unadorned reliance on the principle of equal treatment. Treating both kinds of capital the same has the intuitive appeal of consistency or, if you like, treating like cases alike. If we have two kinds of capital, we should treat them alike. As stated, however, this second argument is oversimple. "A foolish consistency," as Emerson taught us, "is the hobgoblin of little minds." 220 Even assuming that it makes sense to take consistency and equality as starting points, we clearly can justify consistency only if there is no good reason for treating two cases differently.

The most troubling argument that $I$ have found for treating nonhuman separate capital differently than we treat human capital is that it leads us back to the fundamental shortcoming of the Spanish rule which we mentioned at the outset: Classification of income from separate property as community creates insurmountable difficulties insofar as it requires a distinction between income from such property and appreciation in that property.

\section{F. Beyond the Spanish Rule}

Once again, the argument is that if we look closely at the economic meaning of the terms "income" and "appreciation" or "growth," we discover that there is no justifiable basis for distinguishing between "income" from separate property and "appreciation" or "growth" in separate property. It follows logically that a property system that attempts to treat income and growth differently cannot be justified. This, of course, is what the Spanish approach does. It treats the income of separate property as community property; absent some contribution of marital labor, however, it treats the growth in separate property as belonging to the separate property owner, even if the separate property is sold and the growth is captured.

220. W. Ralph Emerson, Self-Reliance, in EsSAys 54 (Houghton \& Mifflin, eds., 1885). 
The argument has been most aptly summarized by Professor Blumberg. As she puts it,

our modern forms of wealth make [the distinction between income and appreciation] illusory. If a spouse decides to invest his separate property in a growth stock for its appreciation, he preserves the separate nature of that property. If, instead, he buys a bond for its interest, the bond generates community income. Moreover, with stocks the choice between interest and appreciation may not even be in the owner's hands. If the company decides to issue a dividend, it is community property. If the company declares no dividend and instead reinvests its profits in capital development, the stock appreciates in value and that appreciation remains separate property .... Furthermore, in the individual business, partnership, or closely-held corporation, the allocation between appreciation and income is in the hands of the managing spouse since he or she decides whether and how much to draw out of the business... The nub of the problem is that appreciation and income are economically indistinguishable. ${ }^{221}$

This argument is particularly troubling because it turns the economic incentive argument around and effectively argues that the income/growth distinction creates inappropriate economic incentives for investing in one kind of separate property as opposed to another. Moreover, insofar as the choice between seeking income and appreciation is in the control of the separate property owner, it allows that spouse unilaterally to deprive the community of an interest in the fruits of separate property. I consider this a powerful objection and believe that if it cannot be overcome, it should be the deathknell of the Spanish rule. Moreover, the argument seems to me incontrovertible insofar as it simply recognizes modern realities about economic productivity.

Nonetheless, the proper response to the foregoing argument is not to retain the American rule, under which both income and appreciation from separate property remain separate. If, as I have suggested, there are good reasons for treating the productive capacity of all property equally, then we should try to make this principle work in the context of modern forms of wealth and investment. Professor Blumberg points the way when she observes that a separate property owner's control over the form of investment will undermine the Spanish rule "[u]nless we develop some notion of imputed income when separate property business income is reinvested rather than withdrawn."222

\section{G. A Proposal for Imputing Income}

Fortunately, there are a variety of relatively easy ways of imputing income where one concludes that income has been buried in appreciation. Professor Bruch has proposed dealing with this problem simply by defining the income of separate property to include what she calls "natural appreciation."223 While perhaps the simplest, this approach would entirely deny the separate property owner the right even to preserve the original value of the separate property in an inflationary economy. Apparently this is part of the appeal of the approach

221. Blumberg, supra note 4, at 100. The same point is made quite briefly by Professor Bruch.

Bruch, supra note 4, at 796 n.105.

222. BLUMBERG, supra note 4 , at 100.

223. Bruch, supra note 4 , at 795 . 
to Professor Bruch, since she sees it as desirable that "the income from separate property would gradually replace the original capital as the property's predominant characteristic."224 But this seems confiscatory of a spouse's separate property stake, and such confiscation of the original capital would not follow from the original argument that justified dedicating the income from separate property to the community. It is the productivity of the separate property that can appropriately be committed to the community, not the separate property itself. Thus, if the appreciation of separate property is to be included in the definition of income, it should be the appreciation after an adjustment for inflation. In short, the spouse's separate property value should be indexed for inflation or deflation, and any appreciation in its value above the adjusted value of the principal should be awarded to the community.

Another approach would be to allocate a certain amount of any appreciation to income, if it can be shown that the property has not yielded a satisfactory amount of income. This approach is slightly more complicated than the first one proposed, but it has the merit of having been tried and tested in the area of trust management. The problem that $I$ have focused on-that of property that has appreciated in value at the expense of generating income-is one well known to trustees. ${ }^{225}$ Often enough, the settlor of a trust directs that one set of beneficiaries is to receive the income while another-often a remainderman-is to receive the principal. To protect the income beneficiaries, the courts have developed rules (articulated in the Restatement on Trusts) that require an allocation of some of the capital growth to the income side when it can be shown that an investment has been unproductive or underproductive of income. ${ }^{226}$ Moreover, the Commissioners on Uniform State Laws promulgated a model statutory version of such an allocation formula as early as $1931,,^{227}$ and a revised version in 1962. ${ }^{228}$ Significantly, the 1962 version of the Uniform Principal and Income Act has been adopted in twenty-nine states, including all the community property states except for Louisiana. ${ }^{229}$ It would take little amendment to adapt either the Restatement or the uniform laws approach to our problem.

The Restatement approach is triggered if property "produces no income or an income substantially less than the current rate of return on trust invest-

224. Id. at 796.

225. In suggesting use of the income allocation rules adopted in trust law, I do not mean to advocate importing other trust doctrines, such as the prudent manager rule. I think the allocation rules can be borrowed without the prudent manager rules. Whether prudent manager rules have a place in marital property law at all is a subject for another article.

226. See, e.g., In re Kuehn, 308 N.W. 2d 398 (S.D. 1981). The rules have been articulated in the Second Restatement of Trusts. RESTATEMENT (SECOND) OF TRUSTS $\$ \$ 240,241$ (1959). I am using the terms "unproductive" and "underproductive" as they are used in the Restatement, to refer to production of income, and not to production of income and/or growth.

227. UNIFORM PRINCIPAL AND INCOME ACT (1931 Act) \& 11, 7B U.L.A. 183, 215 (1985) [hereinafter UPIA].

228. UPIA (1962 Act), § 12, 7B U.L.A. 145, 173 (1985).

229. Id. at 145 . 
ments. "230 It allocates to income beneficiaries an amount equivalent to the "current rate of return on trust investments," and to trust corpus that amount that, had it been invested at the "current rate of return on trust investments" for the time period in question, would have generated the value to which the property has actually grown. ${ }^{231}$ By contrast, the Uniform Act is triggered only if property fails to yield an average net income of at least one percent per year; when this condition is met, the income beneficiary is allocated a share which would correspond to a four percent yield. ${ }^{232}$ Obviously the Restatement rule is more protective of the income beneficiary than is the Uniform Act. By looking at usual rates of return on investments in the market both for its trigger and for its allocation, the Restatement guarantees a share to the income side whenever the property becomes underproductive, whereas the Uniform Act requires the property to become almost entirely unproductive before it is triggered. Moreover, the Restatement rule has the flexibility to reflect varying market conditions over time, because it does not depend on the application of a set percentage. The Restatement rule seems to me to be preferable for both of these reasons, although admittedly it is more complicated to apply and would be applicable in a larger number of cases than would the Uniform Act approach. Ultimately the choice between these two approaches would be a political one which balances the interests of the income beneficiary with those of the owner of principal.

Finally, allocation of a share of capital growth could be left to the discretion of the courts. ${ }^{233}$ In general, this approach raises the more general question of when such an allocation would actually need to be made. Of course it would be appropriate at the termination of the community, either by death or divorce. It might also be necessary to make such an allocation if a community creditor were to obtain a judgment that was not collectable from the separate property of the owner whose separate property had appreciated at the expense of income. In rare cases, it might also be necessary for a court to make such an allocation if one spouse were able to show that the community was being denied the use of significant amounts of potential income by virtue of the other spouse's retention of high growth investments.

230. RESTATEMENT (SECOND) OF TRUSTS $\$ 240$ (1959). The trust rule contained in the Restatement actually requires that a second condition also be met. The trustee must be under a duty to sell the underlying property. This condition would need to be modified if the rule were used to allocate a share of appreciation in the marital context. The rule should be triggered without regard to any duty to sell the separate property. Indeed, the owner of the separate property should be entitled to buy out the income right of the community by a cash payment or some other kind of in lieu payment.

231. Id. $\$ 241(2)$.

232. UPIA (1962 Act) § 12, 7B U.L.A. at 173.

233. The influential California case, Beam v. Bank of America, 490 P.2d 257 (Cal. 1972), for example, left up to the discretion of the court whether to follow a rule that gives a fixed rate of return to community labor and allocates the remaining growth to the separate estate or a rule that gives a fixed rate of return to the separate estate, and allocates the remaining growth to the community. Such a discretionary allocation is also possible, of course, in those states that allow the court at dissolution to divide equitably not only the community or marital property, but also the separate property. E.g., WASH. REV. CODE $\$ 26.09 .080$ (1986). 
It seems to me that an approach to the problem that does not leave such allocation decisions up to the discretion of the courts is preferable. The characterization of income from separate property as community property should be a rule of law that is not up to the discretion of the court. ${ }^{234}$ As a corollary, the determination of how much appreciation should be allocated to the income side should also not be a discretionary decision. Both the separate property owner and the nonowner spouse are entitled to a clear rule so that they can predict how much of the capital growth is community property and how much is separate. ${ }^{235}$ This seems to me essential if we are to be consistent with the idea that it is a community property system that we have in place, and not a deferred community property system. Community property rights should attach upon the acquisition of community income or appreciation, not merely at a later time when a court is required to make a ruling. Management rights may well turn on an ability to properly characterize income and appreciation immediately, and so may creditors' rights.

As between the first two allocation approaches suggested, the trust approach seems to be superior. The Bruch approach, with the modification suggested to preserve the value of the separate property that was brought into the marriage, would be the purest theoretically, in that literally all gain accruing would be dedicated to the community, whether it took the form of dividends, interest, or capital growth. This approach, alone, would deprive the separate property owner of any incentive for investing in a form of growth capital, as opposed to income capital.

On the other hand, while awarding all post-inflationary increase to the community would be the correct approach from a purely theoretical point of view, and at first blush would appear to be simpler, application of this approach has two serious practical limitations that persuade me that the trust approach is superior. First, the modified Bruch approach would trigger the need for allocations in a far greater number of cases than would the trust allocation approach. Many investments that yield income also grow in value. If all growth in value (net of inflation) were to be classified as income for community property purposes, an allocation would need to be made for virtually all investments. By contrast, the trust rule could be applied, as it is in the trust area, only to extreme cases where investments are seriously underproductive of realized income. In that connection, it should be recognized that the usual rate of return for trust investments is traditionally quite low, in part because trustees are being paid for their professional management skills, and in part because trust rules require trustees to be extraordinarily conservative in their investment strategies. Under

234. Nonetheless, equitable power to award a share of appreciation in separate property is present already in Washington and Wisconsin, as well as in many of the common law states, at dissolution.

235. The need for clear rules here is illustrated by the state of confusion that exists currently in community property states when community funds or labor have been commingled with one spouse's separate property. While each state has developed methods of apportionment, many are based on an exercise of judicial discretion. As a consequence, spouses do not really know, until death or divorce, who owns a commingled asset or in what proportions. 
the trust rule, therefore, if an investment realized income at something near the usual rate of return for trust investments, that could be viewed as a sufficient return for the community, and no allocation would be needed, even if unrealized appreciation were enormous. A separate property owner, in turn, would know that he or she would be obliged to provide a reasonable rate of return to the community for any investment that was productive of income or growth.

These observations lead to the second practical reason for preferring the trust rule: It is likely to be "politically" palatable to more separate property owners, since it is less intrusive than the modified Bruch approach. In short, it is more likely to succeed as a matter of political compromise. ${ }^{236}$ Finally, I would add that use of the trust allocation rule seems quite appropriate in the marital context, since the same kinds of fiduciary considerations that led to such rules in the trust context are behind the need to make an allocation between income and principal in a marriage.

Regardless of which approach is followed, however, it seems that either would provide a satisfactory answer to the argument that the inability to distinguish between income and capital growth is fatal to dedicating the income from separate property to the community. The answer concedes the force of the objection, but responds that it can best be dealt with by amending the Spanish rule itself.

\section{$\mathrm{V}$ \\ CONCLUSION}

The community property system, as it came to us from the Spanish, treated the income from a spouse's separate property as part of the community. The historical review in Part II shows that the five community property jurisdictions that abandoned the Spanish rule did so more out of confusion or a misguided attempt to protect wives, than out of sound policy. As the same issue has resurfaced in recent years, although the Commissioners on Uniform State Laws have returned to the original Spanish rule, many jurisdictions continue to miss the insight of that rule. The Spanish rule captures the essential notion that in the community property system, each spouse is expected to dedicate the fruits of all of his or her capital, be it human or nonhuman, to the community during the marriage. At the same time, the discussion has demonstrated that the Spanish rule, itself, is deficient in its failure to consider an owner's ability to invest property productively without generating income, as that concept is understood under the Spanish rule. Consequently, the Spanish rule needs to be modified so as to allocate some or all of capital appreciation to income, and thus to prevent

236. It is interesting to note, however, that something like the equitable approach described in text seems to have been adopted in Tennessee. TENN CODE ANN. \$ 36-4-121(b)(1) (1991). It is only "something like" the equitable approach because Tennessee requires each spouse to have "substantially contributed" to any appreciation in value before it accrues to the marital property. Id. It is doubtful, however, whether such an approach-with or without the "substantial contribution" component-could easily be adopted in a community property state. 
the owner from being able freely to deprive the community of the income that rightfully belongs to it. 